\title{
USE OF WELL-LOGS FOR PETROPHYSICAL EVALUATION OF ABU MADI RESERVOIR IN ABU MADI - EL-QARA - NIDOCO AREA, NORTHERN NILE DELTA, EGYPT
}

\author{
Ghoneimi $A^{1}$, Ibrahim Sh $A^{1}$, El-Kenawy $A^{1}$ and Farrag $\mathrm{Kh}^{2}$ \\ ${ }^{1}$ Geology Department, Faculty of Science, Zagazig University, Egypt. \\ ${ }^{2}$ Consultant Geophysicist.
}

\begin{abstract}
The objective of the present study is to evaluate the reservoir characteristics of the Late Miocene Abu Madi Formation (Abu Madi Levels II and III) at Abu Madi-El-Qara-Nidoco area, northern Nile Delta, Egypt. The study area is located between Longitude $31^{\circ} 13^{\prime} 48^{\prime \prime}-31^{\circ} 24^{\prime} 36^{\prime \prime} \mathrm{E}$ and Latitude $31^{\circ} 21^{\prime} 36^{\prime \prime}-31^{\circ} 37^{\prime} 12^{\prime \prime} \mathrm{N}$. Open-hole wireline log data of seven wells are used in this study. The petrophysical characteristics of the studied formation are thoroughly investigated to elucidate its hydrocarbon potentialities. The vertical variation of the petrophysical characteristics is presented as Lithosaturation cross-plots. The parameters distribution maps (shale volume, porosity, fluid saturation, net pay thickness and hydrocarbon saturation) are constructed to represent the lateral variation of petrophysical characteristics. The shale model shows that the dominant shale is mainly of dispersed and laminated types. The constructed neutron-bulk density, neutron-sonic and M$\mathrm{N}$ crossplots display that the main reservoir lithology is sandstone intercalated mainly with dispersed shale and minor laminated shale in Level III and dispersed to laminated shale in Level II. It is also shown that Abu Madi Formation has poor to very good porosities range from 0.03 to 0.22 for Level II and from 0.06 to 0.19 for Level III. The most favorable places for hydrocarbon reservoirs occupy southwestern part for Abu Madi Level II reservoir and in the middle, the middle-west, the middle-east and the southeastern parts for Abu Madi Level III reservoir.
\end{abstract}

Keywords: Petrophysical parameters; Shale content $\left(V_{s h}\right)$; Effective porosity $\left(\emptyset_{\text {eff }}\right.$ ); Shale type; Net reservoir (reservoir flag); Net pay (pay flag). 


\section{Introduction}

The Nile Delta basin contains a thick sequence of Neogene-Quaternary clastics that are considered to be prospective for oil and gas. The northern parts of the onshore area and the offshore parts are favorable sites for hydrocarbon generation and accumulation (Zaghloul et al., 1977b). The main proven reservoir within the Miocene (Messinian) deltaic sequences of the northern Delta basin is Abu Madi sandstone (Barakat and Dominik 2010).

The recent discoveries in the Nile Delta make it one of the most world known deltas. Abu Madi-El-Qara-Nidoco area is a giant field located in the northeastern part of the Nile Delta. Abu Madi field is the first commercial discovery in the Nile Delta. The IEOC achieved the first gas discovery from the early Pliocene Abu Madi formation in the northeastern part of the onshore delta by drilling the Abu Madi-1 well. Two pay zones were encountered with more than $50 \mathrm{~m}$ thick gas and condensate bearing sands in Abu Madi Formation. The field was put on production in 1975 and was producing 355 MMSCF per day in 1995 (EGPC 1994).

The study area is located in the northern area of the Nile Delta between Longitude $31^{\circ} 13^{\prime} 48^{\prime \prime}-31^{\circ} 24^{\prime} 36^{\prime \prime}$ E and Latitude $31^{\circ} 21^{`} 36^{\prime \prime}$ $31^{\circ} 37^{\prime} 12^{\prime \prime}$. Seven wells (AM-16, AM-18, AM-20, AM-21, El-Qara-3, Nidoco-7 and Nidoco-10) were selected to evaluate Abu Madi Formation (Figure 1). The subsurface Abu Madi Formation includes thick bodies of cross-bedded sandstones that are occasionally pebbly with thin shale interbeds, in Abu Madi Well-1 type section. The lower part of the formation is the most sand rich (level III), passing up into interbedded sandstones and siltstones with shale streaks (level II), to predominantly shales in the upper part (level I) (El-Heiny and Morsi 1992).

The main objective of the present study is to perform comprehensive evaluation of the hydrocarbon reservoir. The quantitatively interpreted reservoir petrophysical parameters include the shale content, effective porosity, and water and hydrocarbon saturations. Construction of the lithosaturation crossplots in addition to distribution parameters maps (effective porosity, shale volume, water saturation and hydrocarbon saturation) have been accomplished to represent the vertical and lateral distribution of petrophysical parameters of the two reservoirs rock units (Abu Madi level II and Abu Madi Level III).

\section{Geological settings}

In general, the Nile Delta has a featureless surface with a northward slope, except for some limited topographic features such as the Khatatba positive structural and the westward Wadi El-Natrun negative element (Azzam, 1994). 
The Nile Delta is an old feature which started to build by the advent of the Upper Pliocene and took its form by the beginning of the Pleistocene (Said, 1973). Almost of the northern Egypt was covered by the Carboniferous sea (Kostandi, 1959). More than $1500 \mathrm{~m}$ of the Paleozoic sediments were accumulated in the center of the Carboniferous sea (El-Gezeery et al., 1972). Mesozoic beds were penetrated only in a few wells across the middle and southern parts of the Nile Delta because of the northward thickening of Tertiary section (Said, 1990). Near the hinge line, the wells penetrating the Pre-Miocene formations include the series from Upper Jurassic to Oligocene. They consist of typical close to shore shelf and lagoonal deposits (EGPC1994, Schlumberger 1984 and Kamel et al., 1998).

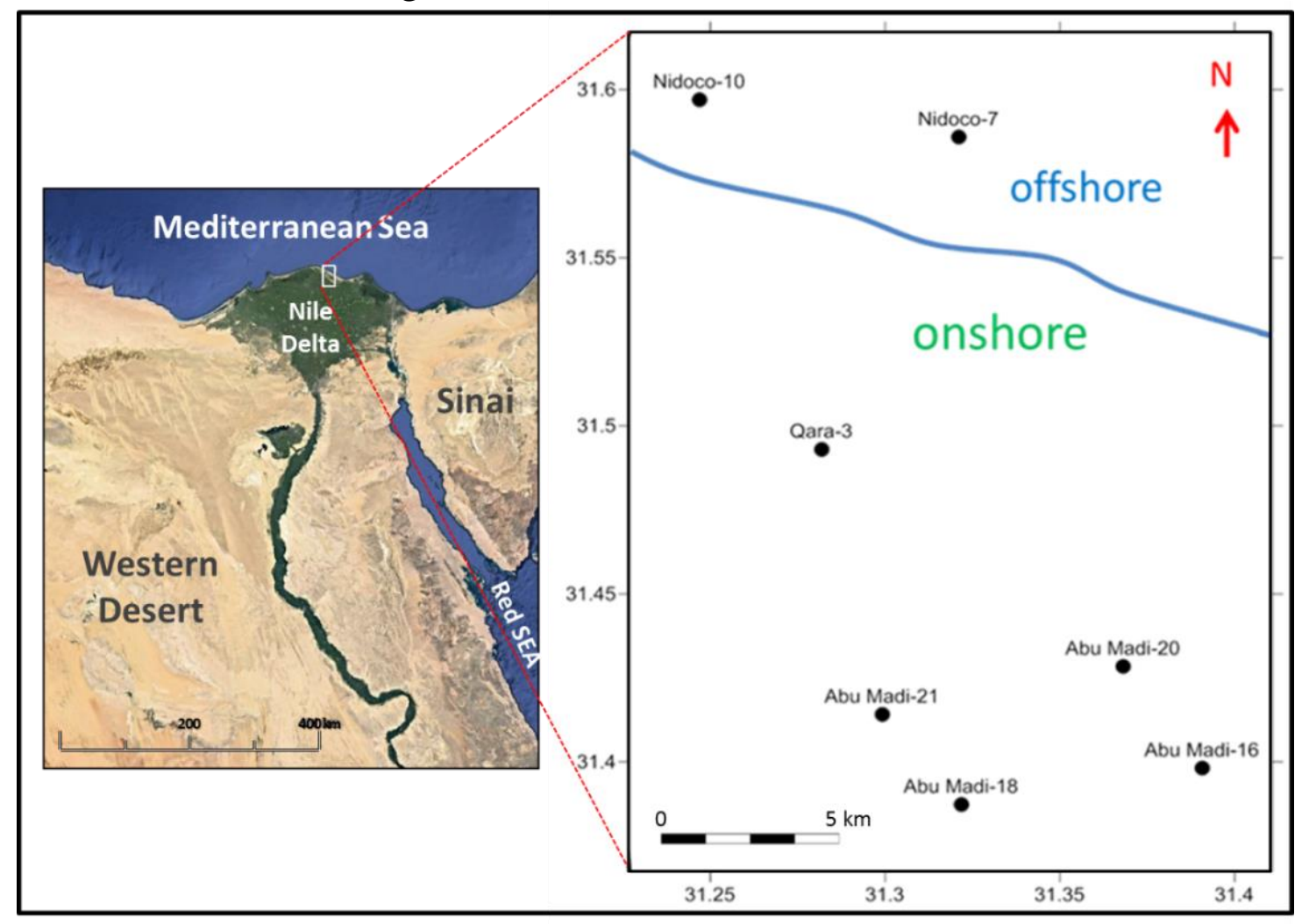

Figure (1): Location map of the study area showing well locations.

Paleocene and Eocene sediments in the Western Desert and the western side of the Delta were mainly deposited in narrow and elongated basins trending northeast-southwest. This situation most probably extends to the area of the Nile Delta (Salem, 1976). The Early to Middle Eocene were deposited in a narrow elongated $\mathrm{E}-\mathrm{W}$ trending basin with a distinct flexure zone in the midDelta area (Zaghloul et al., 1999). Oligocene sediments are represented by the Tineh Formation of Late Oligocene-Early Miocene age, which is composed of a series of marine to fluvio-marine shales and sandstone interbeds (El-Heiny and Enani 1996). 
Neogene-Quaternary rock units in the Nile Delta area were grouped into three sedimentary cycles with different environmental parameters (Zaghloul et al., 1977a). The Neogene-Quaternary subsurface succession in the northern part of the Nile Delta basin has been subdivided into eight formations arranged from base to top: Sidi Salem, Qawasim, Rosetta, Abu Madi, Kafr El-Sheikh, El-Wastani, Mit Ghamr and Bilqas formations (EGPC 1994, El-Heiny and Enani 1996 and Rizzini et al., 1978). The generalized litho-stratigraphic column, of the Abu Madi area (El-Heiny and Enani 1996) is shown in (Figure 2).

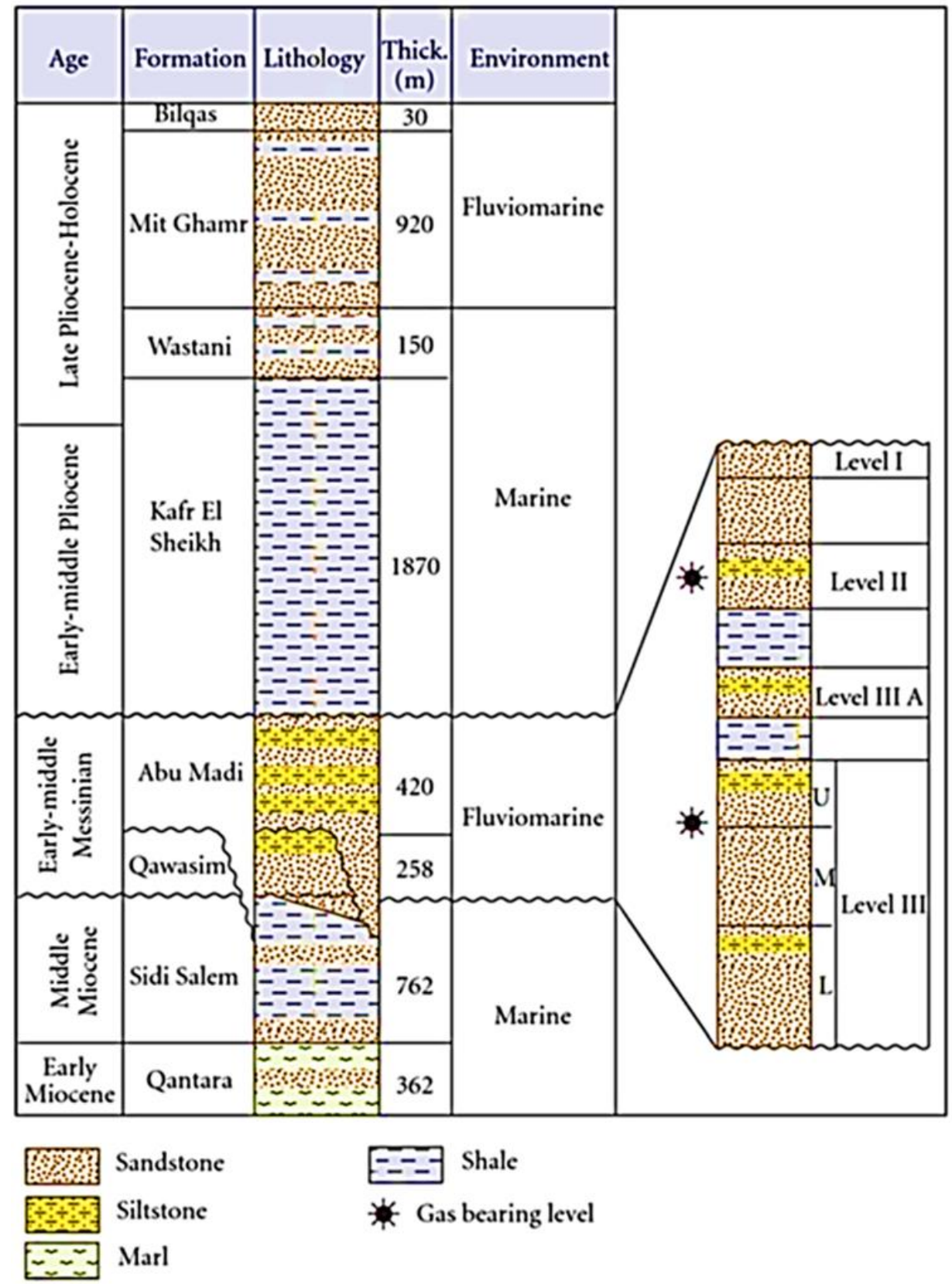

Figure (2): Generalized Lithostratigraphic column of Abu Madi gas field (Modified after El-Heiny and Enani, 1996). 
The Nile Delta is divided into two geological provinces; the deep offshore Nile Delta province, north of the continental shelf and the onshore Nile delta province. The onshore Nile Delta is subdivided by the Hinge Zone into the South Nile Delta block and the North Nile Delta basins (EGPC 1994, Kamel et al., 1998 and Shata and El-Fayoumy 1970).

\section{Available well log data}

The open hole wireline log data, including caliper CL, gamma ray GR, spontaneous potential SP, formation density RHOB, neutron porosity NPHI, sonic DTL and resistivity logs shallow and deep LLD, LLS, MSFL, ILD, ILM, AT10, AT 90 of seven wells, (AM-16, AM-18, AM-20, AM-21, El Qara-3, Nidoco-7 and Nidoco-10) are used in this study (Table 1). Table 2 contains petrophysical constants used in the log data analysis.

\section{Data editing}

The available electrical $\operatorname{logs}$ (Table 1), for all studied wells were digitized by converting field analog prints into digital data, (by taking readings every 0.5 $\mathrm{m}$. on the field analog prints), which can be stored as a log data base for easy access and retrieval, also to be easy used of these digits in model calculations. The prepared digital data had been converted into ASCII formats. These formatted data were restored on the PC computer; it runs after that with certain package known as interactive petrophysics software (IP).

\section{Results and Discussion}

\section{Log data analysis}

The gamma ray, density, neutron and sonic logs are used as lithology and porosity indicators. The neutron-density, neutron-sonic and M-N cross-plots are used to determine lithology (Schlumberger, 1972, Schlumberger, 1974, Asquith and Gibson 1982 and Rider, 1986).

Table (1): The available open hole wireline logs for studied wells.

\begin{tabular}{|l|l|}
\hline \multicolumn{1}{|c|}{ Well name } & \multicolumn{1}{c|}{ Available well logs } \\
\hline AM-16 & CL, GR, SP, RHOB, NPHI, DTL, LLD, LLS, and MSFL \\
\hline AM-18 & CL, GR, SP, RHOB, NPHI, DTL, ILD and MSFL, \\
\hline AM-20 & CL, GR, SP, RHOB, NPHI, DTL, ILD and MSFL, \\
\hline AM-21 & CL, GR, SP, RHOB, NPHI, DTL, ILD, ILM and MSFL \\
\hline El-Qara-3 & GR, RHOB, NPHI and DTL \\
\hline Nidoco-7 & CL, GR, SP, RHOB, NPHI, DTL, AT 90 and AT 10 \\
\hline Nidoco-10 & CL, GR, RHOB, NPHI, DTL, AT 90 and AT 10 \\
\hline
\end{tabular}


Table (2): Petrophysical constants used in log data analysis.

\begin{tabular}{|c|c|c|c|c|c|c|c|}
\hline Parameters & $\begin{array}{c}\text { Nidoco- } \\
7 \\
\end{array}$ & $\begin{array}{c}\text { Nidoco- } \\
10 \\
\end{array}$ & $\begin{array}{c}\text { AM- } \\
16\end{array}$ & $\begin{array}{c}\mathrm{AM}- \\
18 \\
\end{array}$ & $\begin{array}{c}\text { AM- } \\
20 \\
\end{array}$ & $\begin{array}{c}\text { AM- } \\
21 \\
\end{array}$ & $\begin{array}{c}\text { El-Qara- } \\
\mathbf{3} \\
\end{array}$ \\
\hline$G_{\text {min }}(A P I)$ & 8.2 & 17 & 10 & 18 & 11.5 & 12 & 13 \\
\hline GR max. (API) & 60 & 49 & 52 & 62 & 60 & 61 & 82 \\
\hline$\rho_{\text {mat. }}(\mathrm{gm} / \mathrm{cc})$ & 2.65 & 2.65 & 2.65 & 2.65 & 2.65 & 2.65 & 2.65 \\
\hline$\rho_{\mathrm{f}}(\mathrm{gm} / \mathrm{cc})$ & 1 & 1 & 1 & 1 & 1 & 1 & 1 \\
\hline$\rho_{\text {clay }}(\mathrm{gm} / \mathrm{cc})$ & 2.95 & 2.59 & 2.55 & 2.53 & 2.73 & 2.73 & 2.58 \\
\hline$\Delta t_{\text {mat. }}(\mu \mathrm{s} / \mathrm{ft})$ & 55.5 & 55.5 & 55.5 & 55.5 & 55.5 & 55.5 & 55.5 \\
\hline$\Delta t_{f}(\mu \mathrm{s} / \mathbf{f t})$ & 189 & 189 & 189 & 189 & 189 & 189 & 189 \\
\hline$\Delta t_{\text {clay }}(\mu \mathrm{s} / \mathrm{ft})$ & 119 & 105 & 112 & 125.75 & 103.5 & 103.5 & 90 \\
\hline $\mathbf{a}$ & 1.00 & 1 & 1 & 1 & 1 & 1 & 1 \\
\hline $\mathbf{m}$ & 2.00 & 2 & 2 & 2 & 2 & 2 & 2 \\
\hline $\mathbf{n}$ & 2.00 & 2 & 2 & 2 & 2 & 2 & 2 \\
\hline $\begin{array}{c}\text { Surface temp. } \\
\text { (Celsius) }\end{array}$ & 27 & 24.5 & 25 & 32.78 & 28.88 & 30 & 27 \\
\hline $\begin{array}{c}\text { Bottom-hole } \\
\text { temp. } \\
\text { (Celsius) } \\
\end{array}$ & 104 & 104 & 99 & 101.7 & 101 & 93 & 104 \\
\hline Total depth (m) & 3689 & 3686 & 3443 & 3346.6 & 3417.5 & 3342 & 3485 \\
\hline $\begin{array}{c}\mathbf{R}_{\mathrm{m}}(\mathbf{o h m m}) \\
\text { (at .... Celsius) }\end{array}$ & $\begin{array}{l}0.458 \\
\text { (at 31) } \\
\end{array}$ & $\begin{array}{l}0.458 \\
\text { (at 31) }\end{array}$ & $\begin{array}{l}0.735 \\
\text { (at 25) } \\
\end{array}$ & $\begin{array}{l}0.546 \\
\text { (at 40) }\end{array}$ & $\begin{array}{l}0.515 \\
\text { (at 34) } \\
\end{array}$ & $\begin{array}{l}0.114 \\
\text { (at 30) }\end{array}$ & $\begin{array}{l}0.455 \\
\text { (at 27) }\end{array}$ \\
\hline $\begin{array}{c}\mathbf{R}_{\mathrm{mf}}(\mathbf{o h m m}) \\
\text { (at ..... Celsius) }\end{array}$ & $\begin{array}{l}0.282 \\
\text { (at 27) }\end{array}$ & $\begin{array}{l}0.282 \\
\text { (at 27) }\end{array}$ & $\begin{array}{l}0.450 \\
\text { (at 25) } \\
\end{array}$ & $\begin{array}{l}0.383 \\
\text { (at 33) } \\
\end{array}$ & $\begin{array}{r}0.325 \\
\text { (at 23) } \\
\end{array}$ & $\begin{array}{l}0.091 \\
\text { (at 30) } \\
\end{array}$ & $\begin{array}{l}0.298 \\
(\text { at } 22) \\
\end{array}$ \\
\hline $\begin{array}{c}\mathbf{R}_{\mathrm{mc}}(\mathbf{o h m m}) \\
\text { (at ..... Celsius) }\end{array}$ & $\begin{array}{l}0.642 \\
\text { (at 31) }\end{array}$ & $\begin{array}{l}0.642 \\
\text { (at 31) }\end{array}$ & $\begin{array}{l}0.985 \\
\text { (at 25) }\end{array}$ & $\begin{array}{c}1.4 \\
\text { (at 26) }\end{array}$ & $\begin{array}{l}0.763 \\
\text { (at 31) }\end{array}$ & $\begin{array}{c}0.14 \\
\text { (at 30) }\end{array}$ & $\begin{array}{c}0.79 \\
\text { (at 21) }\end{array}$ \\
\hline $\begin{array}{c}\mathbf{R}_{\mathrm{w}}(\mathbf{o h m m}) \\
\text { (at .... Celsius) }\end{array}$ & $\begin{array}{c}0.27 \\
\text { (at } 24)\end{array}$ & $\begin{array}{c}0.14 \\
\text { (at } 24.5 \text { ) }\end{array}$ & $\begin{array}{c}0.13 \\
\text { (at 24) }\end{array}$ & $\begin{array}{c}0.12 \\
\text { (at 24) }\end{array}$ & $\begin{array}{c}0.15 \\
\text { (at } 24)\end{array}$ & $\begin{array}{l}0.134 \\
\text { (at 24) }\end{array}$ & -- \\
\hline Bit size (in) & 8.5 & 8.5 & 8.5 & 8.5 & 8.5 & 8.5 & ------- \\
\hline
\end{tabular}

In the IP program, the 'Rw from SP' module is used to create a continuous $\mathrm{Rw}$ curve $\left(R w_{s p}\right)$. This is useful for estimating $\mathrm{Rw}$ values over a number of zones. We enter the baseline-shifted SP curve and formation temperature curve. The result $R w_{s p}$ curve is calculated and corrected to the output temperature.

The calculated $R_{w}$ of Abu Madi Formation in wells AM-18, AM-20, AM-21 and Nidoco-7 ranging between 0.04 to $0.05 \mathrm{Ohm}$.m. The value in well AM-16 ranging between 0.04 to $0.07 \mathrm{ohm} . \mathrm{m}$. the graphical technique, where the mono porosity crossplot (Pickett crossplot) is constructed between the resistivity of uninvaded zone and the porosity deduced from any porosity tools (Schlumberger, 1972, Schlumberger, 1974, Asquith and Gibson 1982 and Rider, 1986), this method had been used to calculate $R_{w}$ of Abu Madi Formation in well Nidoco-10, where SP log is not available in this well. The $R_{w}$ value in this well (Nidoco-10) is ranging between 0.02 to $0.05 \mathrm{ohm} . \mathrm{m}$. 
Shale content $\left(V_{s h}\right)$ is calculated from the combination of density and neutron logs using the double clay indicator and the GR clay indicator using the linear method. The determination of effective porosity $\left(\emptyset_{\text {eff }}\right)$ is executed in both clean and shaly rock units by the combination of the density and neutron logs measurement by using a mathematical equation of Poupan and Gaymard (Schlumberger, 1972, Schlumberger, 1974, Asquith and Gibson 1982 and Rider, 1986).

The Archie's water saturation equations assume that the formation water is the only electrically conductive material in the formation. The presence of shale requires the existence of another conductive material other than water. The dual water model is an elaborated model to explain the effects of clay on resistivity. In the dual water model the water saturation formation behaves as if it contain two types of water, the first one is the water near the clay (clay water or bound water) this water is salt free and its conductivity is independent of the counter ion concentrations and type of clay. The second type is the water far from the clay surface (far water) (Clavier et al., 1977).

The Porosity and Water Saturation interpretation module is used to interactively calculate porosity (PHI), water saturation $(\mathrm{Sw})$, flushed zone water saturation (Sxo), matrix density (RHOMA), hydrocarbon density (RHOHY) and wet and dry clay volumes (VWCL and VDCL). The set-up screens allow us to select 'default' porosity and water saturation models which will initiate the 'Porosity and Water Saturation Parameters' display.

The well $\log$ analysis is concentrated on Abu Madi Levels II and III reservoirs. The shale type is determined by choosing the shale model, which reflects the dominant shale types. The shale types are dispersed and few laminated in Level III, but it is dispersed to laminated in Level II. The Petrophysical parameters evaluation results of levels II and III are summarized and presented in Tables (3 and 4). Also, the average petrophysical parameters are presented as histogram (Figures 3 and 4).

\section{Evaluation of lithological components}

Logs are used as indicators of lithology. The most useful logs for this purpose are gamma-ray, density, neutron, and sonic logs. Lithology identification charts (Dia-porosity and Tri-porosity cross-plots,) are important in formation evaluation processes.

A number of density-neutron, neutron-sonic and MN cross-plots are used through the Interactive Petrophysics software for lithology identification. Figures (5 and 6) are shown as an example to represent neutron-density crossplots of Abu Madi levels II and III in the available wells. 
Table (3): Petrophysical parameters evaluation results, Abu Madi Formation, Level II reservoir unit.

\begin{tabular}{|c|c|c|c|c|c|c|c|c|c|c|c|c|}
\hline \multirow{2}{*}{ Well name } & \multicolumn{9}{|c|}{ Petrophysical parameters (Level II) } \\
\cline { 2 - 13 } & \multicolumn{3}{|c|}{$V_{\text {sh }}$} & \multicolumn{3}{c|}{$\emptyset_{\text {eff }}$} & \multicolumn{3}{c|}{$S_{w}$} & \multicolumn{3}{c|}{$S_{h}$} \\
\cline { 2 - 12 } & Min. & Max. & Ava. & Min. & Max. & Ava. & Min. & Max & Ava. & Min. & Max & Ava. \\
\hline AM-16 & 0.28 & 0.76 & 0.58 & 0.05 & 0.41 & 0.16 & 0.33 & 1.00 & 0.54 & 0.00 & 0.67 & 0.46 \\
\hline AM-18 & 0.12 & 0.65 & 0.42 & 0.02 & 0.25 & 0.12 & 0.04 & 1.00 & 0.47 & 0.00 & 0.96 & 0.53 \\
\hline AM-20 & 0.49 & 0.89 & 0.71 & 0.03 & 0.21 & 0.07 & 0.39 & 1.00 & 0.97 & 0.00 & 0.61 & 0.03 \\
\hline AM-21 & 0.1 & 0.55 & 0.28 & 0.12 & 0.30 & 0.22 & 0.01 & 0.70 & 0.12 & 0.30 & 0.99 & 0.88 \\
\hline El-Qara-3 & 0.13 & 0.71 & 0.47 & 0.01 & 0.22 & 0.08 & - & - & - & - & - & - \\
\hline Nidoco-7 & 0.14 & 0.65 & 0.19 & 0.09 & 0.37 & 0.19 & 0.45 & 1.00 & 0.68 & 0.00 & 0.55 & 0.32 \\
\hline Nidoco-10 & 0.48 & 0.80 & 0.64 & 0.01 & 0.08 & 0.03 & 0.58 & 1.00 & 0.99 & 0.00 & 0.42 & 0.01 \\
\hline
\end{tabular}

Table (4): Petrophysical parameters evaluation results, Abu Madi Formation, Level III reservoir unit.

\begin{tabular}{|c|c|c|c|c|c|c|c|c|c|c|c|c|}
\hline \multirow[t]{3}{*}{ Well name } & \multicolumn{12}{|c|}{ Petrophysical parameters (Level III) } \\
\hline & \multicolumn{3}{|c|}{$V_{s h}$} & \multicolumn{3}{|c|}{$\emptyset_{\text {eff }}$} & \multicolumn{3}{|c|}{$S_{w}$} & \multicolumn{3}{|c|}{$S_{h}$} \\
\hline & $\min$ & $\max$ & Ava & Min & $\max$ & Ava & Min & Max & Ava & Min & Max & Ava \\
\hline AM-16 & 0.07 & 0.65 & 0.24 & 0.04 & 0.23 & 0.16 & 0.18 & 1.00 & 0.44 & 0.00 & 0.82 & 0.56 \\
\hline AM-18 & - & - & - & - & - & - & - & - & - & - & - & - \\
\hline AM-20 & 0.03 & 0.63 & 0.21 & 0.06 & 0.25 & 0.17 & 0.01 & 1.00 & 0.19 & 0.00 & 0.99 & 0.81 \\
\hline AM-21 & - & - & - & - & - & - & - & - & - & - & - & - \\
\hline El-Qara-3 & 0.14 & 0.58 & 0.28 & 0.01 & 0.17 & 0.11 & - & - & - & - & - & - \\
\hline Nidoco-7 & 0.12 & 0.60 & 0.19 & 0.12 & 0.24 & 0.19 & 0.31 & 1.00 & 0.55 & 0.00 & 0.69 & 0.45 \\
\hline Nidoco-10 & 0.16 & 0.69 & 0.47 & 0.01 & 0.24 & 0.06 & 0.09 & 1.00 & 0.33 & 0.00 & 0.91 & 0.67 \\
\hline
\end{tabular}

These cross-plots reflect that the main lithology type in Abu Madi level III is sandstone intercalated with shale in AM-16, AM-20, El-Qara-3, Nidoco-7 and Nidoco-10 wells (where the level is not recorded in wells AM-18 and AM21), while the lithology type in Level II is shaly sandstone in wells AM-18, AM-21, El-Qara-3 and Nidoco-7, but it is sandy-shale in wells AM-16, AM20 and Nidoco- 10. 


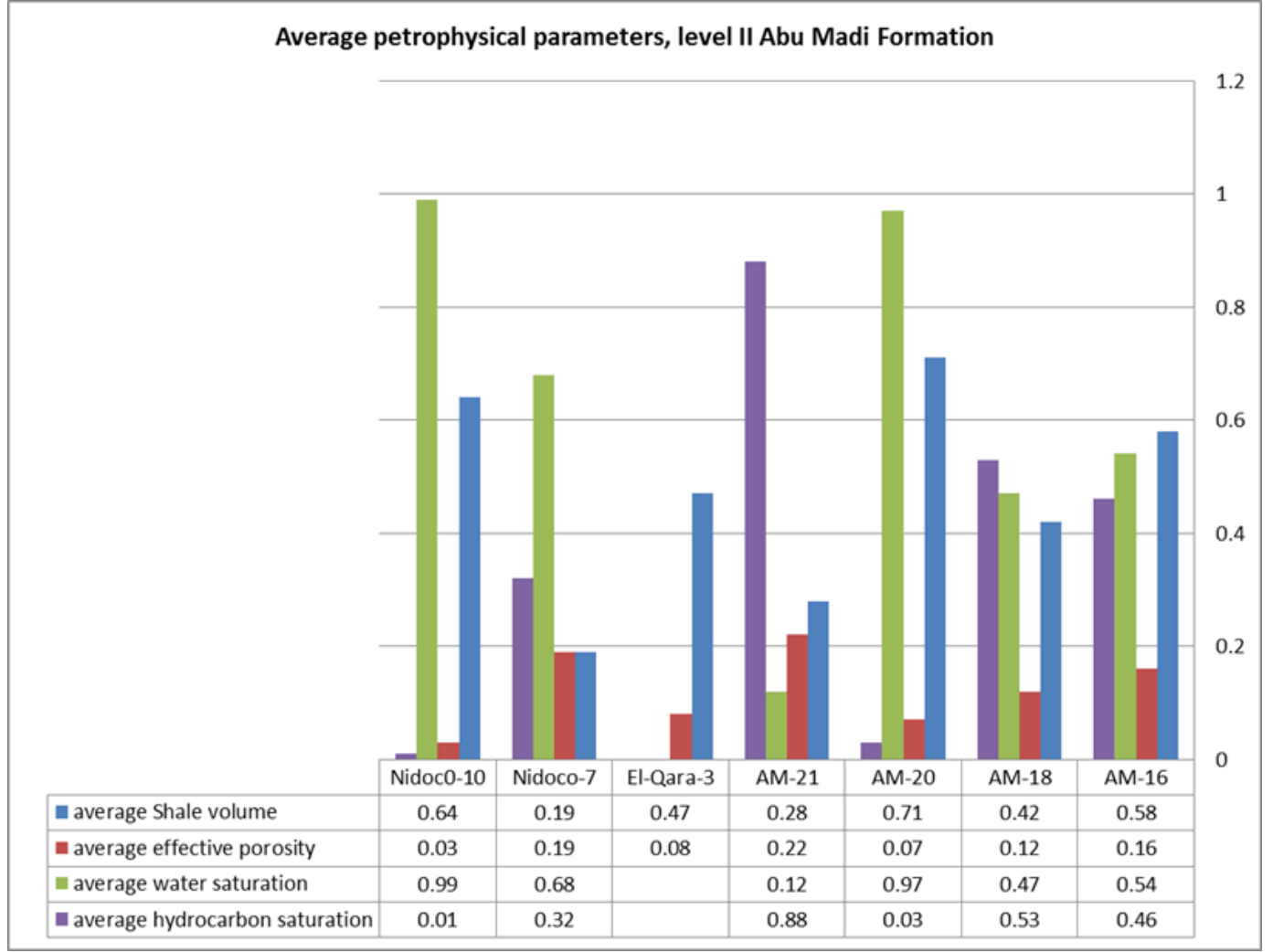

Figure (3): Average petrophysical parameters, level II, Abu Madi Formation.

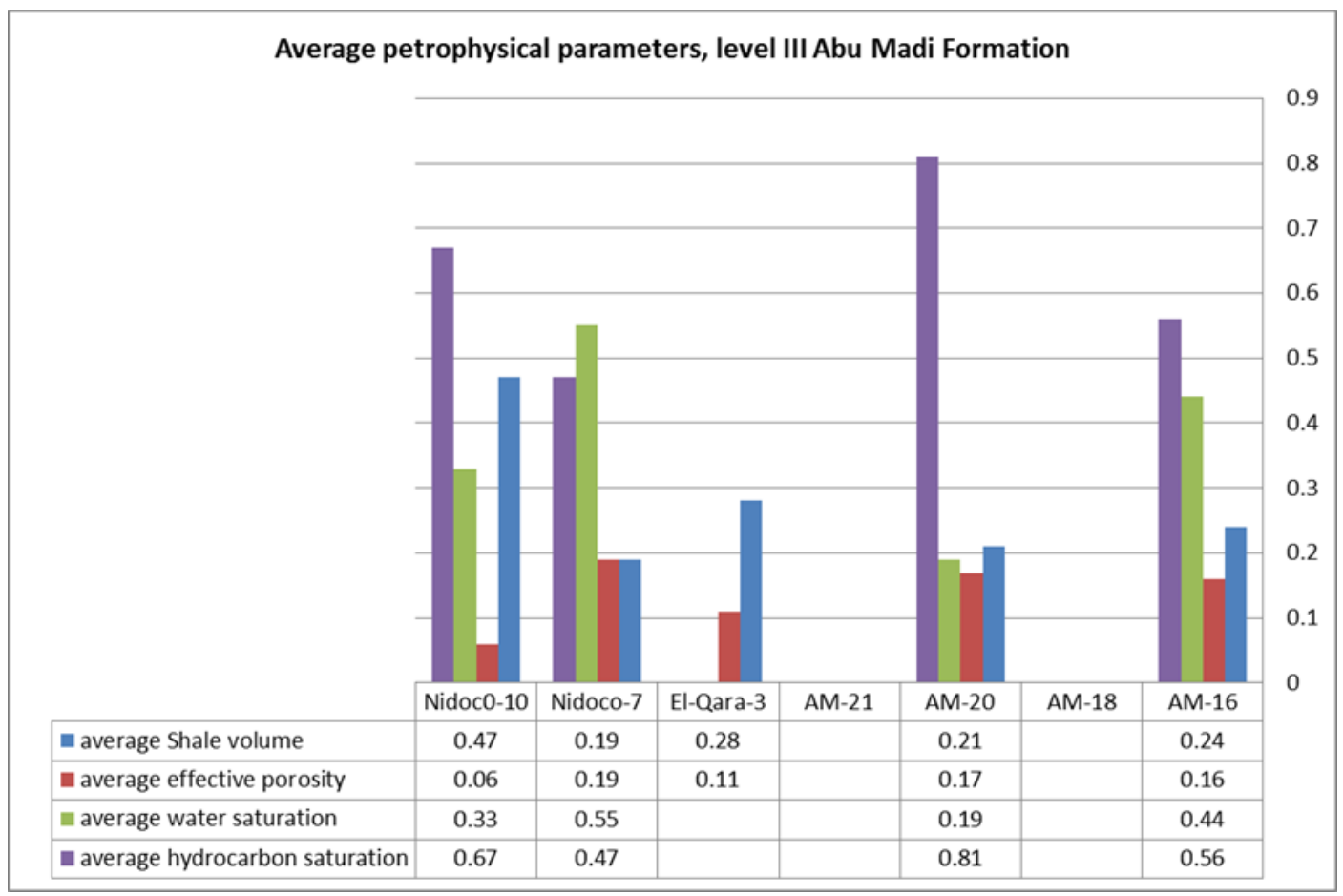

Figure (4): Average petrophysical parameters, level III, Abu Madi Formation. 

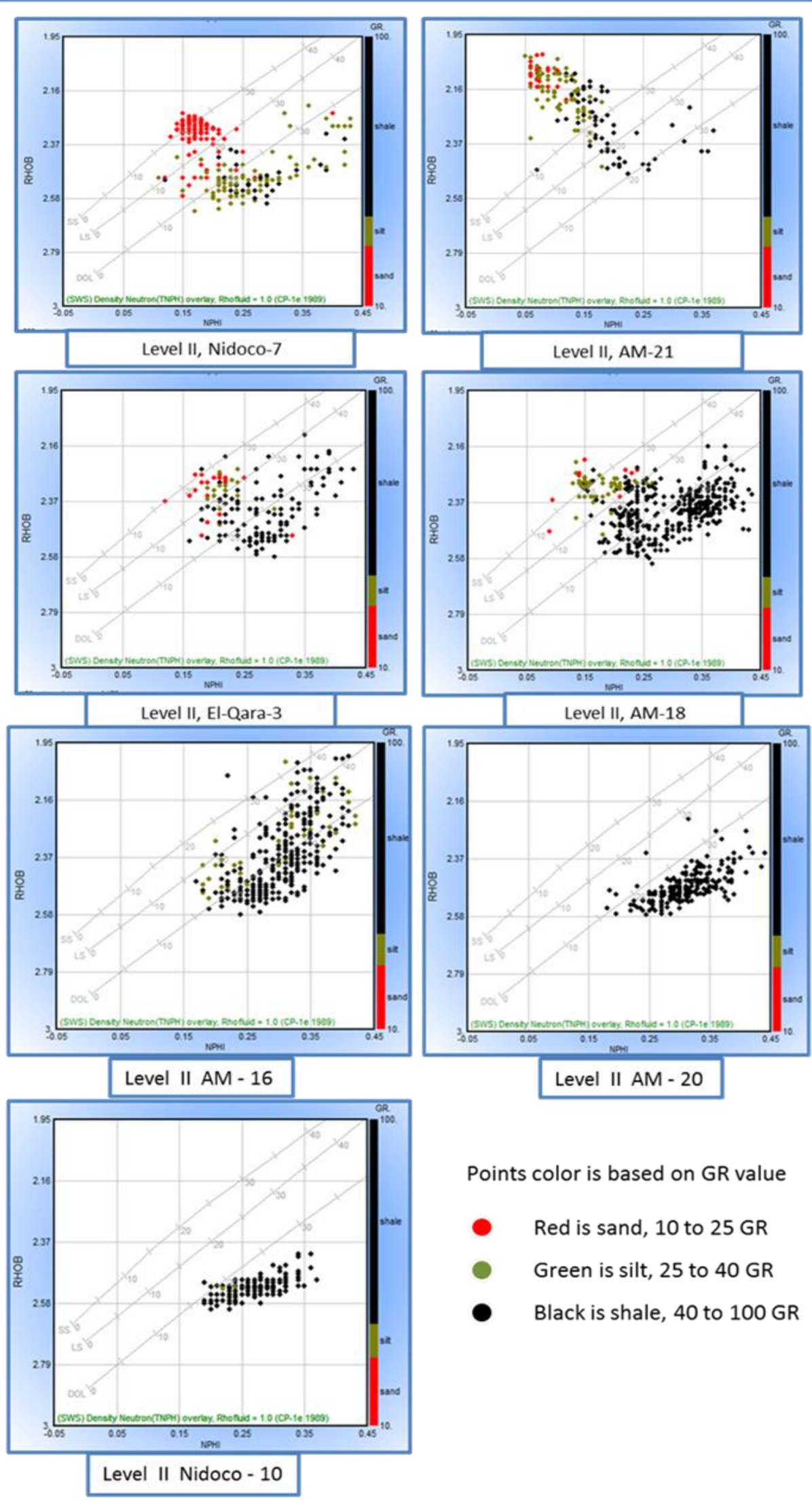

Points color is based on GR value

- Red is sand, 10 to 25 GR

- Green is silt, 25 to $40 \mathrm{GR}$

- Black is shale, 40 to $100 \mathrm{GR}$

Figure (5): Neutron-density crossplot of Abu Madi level II reservoir. 

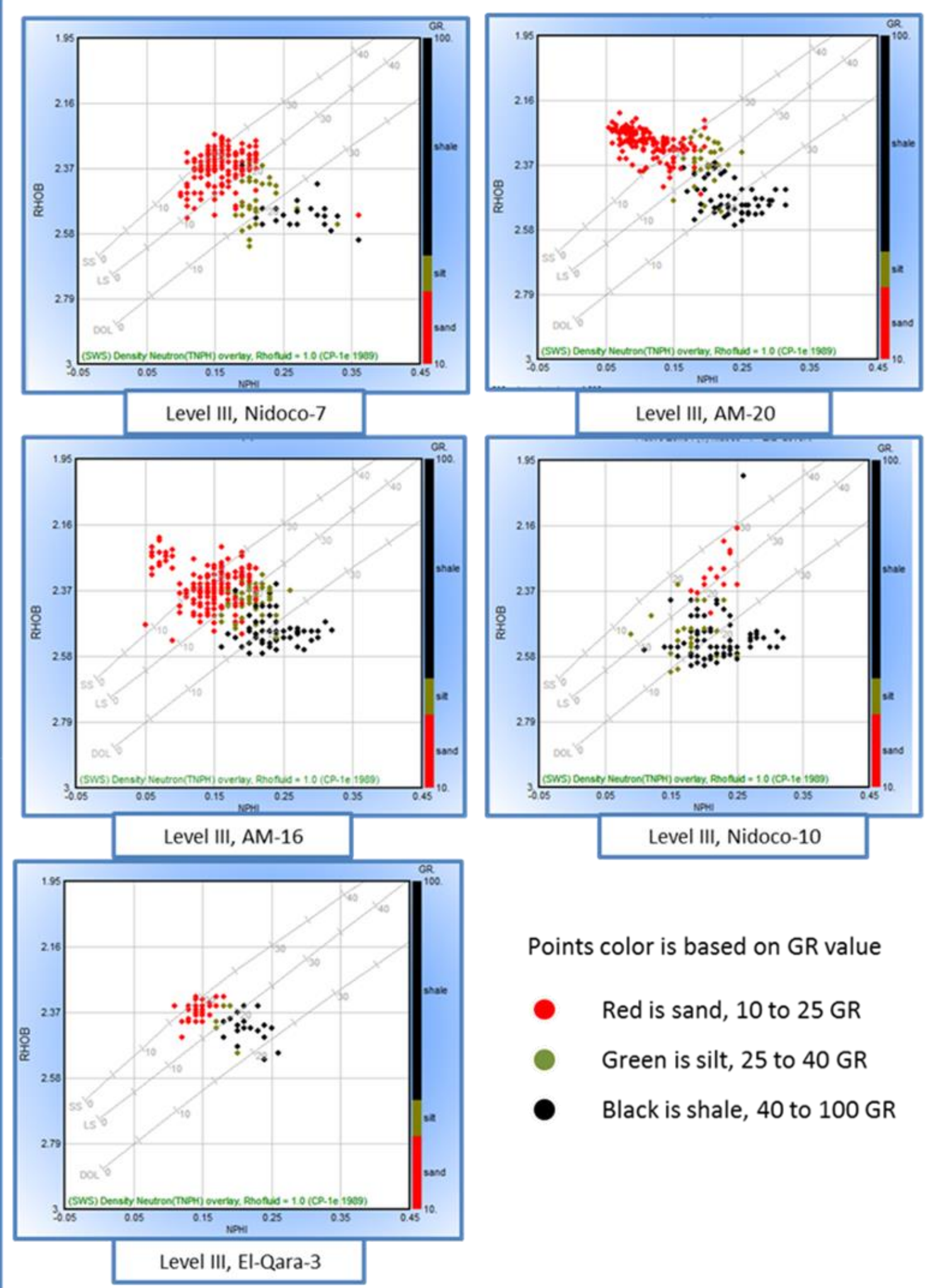

Points color is based on GR value

- Red is sand, 10 to 25 GR

- Green is silt, 25 to $40 \mathrm{GR}$

- Black is shale, 40 to $100 \mathrm{GR}$

Figure (6): Neutron-density crossplot of Abu Madi level III reservoir. 


\section{Lithosaturation crossplots}

The vertical variation of hydrocarbon occurrences, lithology, porosity, saturation and net pay zones are presented as lithosaturation crossplots.

The net reservoir and net pay intervals in the wells have been presented in (Table 5) and as histogram on Figure (7). The lithosaturation crossplots for the studied wells are summarized as petrophysical and lithological characteristics (Figure 8), petrophysical and fluids saturation parameters (Figure 9) and net reservoir and net pay intervals (Figure 10).

Figure 8 contains two lithology tracks for each well, one of these tracks contain a display showing the proportion of the total rock for wet clay, silt, sand and porosity. The second track display clay/shale type. From the figure, the lithology of level II is sandy shale in wells AM-16, AM-20, El-Qara-3 and Nidoco-10, while it is shally sandstone in wells AM-18, AM-21 and Nidoco7. The shale type of level II is dispersed to laminated shale type. The lithology of level III is mainly sandstone with intercalated shale. The shale type in level III is dispersed, with some lamina in the top of the level.

Figure 9 contains porosity and saturation tracks. The saturation track contains the computed curves $S_{w} T u, S_{x o} T u$ and $S_{w}$, when the dual water model is chosen. The porosity track will contain the total and effective porosities computed curves plus a moveable oil plot. The two tracks have shown the vertical variation of the displayed parameters.

Figure 10 contains the porosity Input track, which includes the neutron, density and sonic curves and The Cut-offs module track, which allows the user to interactively define Net Reservoir and Net Pay and to calculate the average petrophysical properties of porosity, saturation and shale volume. The two tracks have shown the vertical variation of the displayed parameters.

Table (5): Thickness for net reservoir and net pay intervals in Abu Madi levels II and III.

\begin{tabular}{|c|c|c|c|c|c|c|}
\hline \multirow{2}{*}{ Well name } & \multicolumn{4}{|c|}{ Thickness Level III (m.) } & \multicolumn{2}{c|}{ Thickness Level II (m.) } \\
\cline { 2 - 7 } & $\begin{array}{c}\text { Total } \\
\text { thickness }\end{array}$ & $\begin{array}{c}\text { Net } \\
\text { Reservoir }\end{array}$ & $\begin{array}{c}\text { Net } \\
\text { Pay }\end{array}$ & $\begin{array}{c}\text { Total } \\
\text { thickness }\end{array}$ & $\begin{array}{c}\text { Net } \\
\text { Reservoir }\end{array}$ & $\begin{array}{c}\text { Net } \\
\text { Pay }\end{array}$ \\
\hline AM-16 & 152 & 132 & 110 & 178 & - & - \\
\hline AM-18 & - & - & - & 205 & 101 & 90 \\
\hline AM-20 & 117 & 97 & 85 & 110.5 & - & - \\
\hline AM-21 & - & - & - & 80 & 75 & 75 \\
\hline El-Qara-3 & 66 & 54 & & 173 & 50 & - \\
\hline Nidoco-7 & 160 & 153 & 65 & 152.5 & 95 & - \\
\hline Nidoco-10 & 59 & 30 & 22 & 88.5 & - & - \\
\hline
\end{tabular}




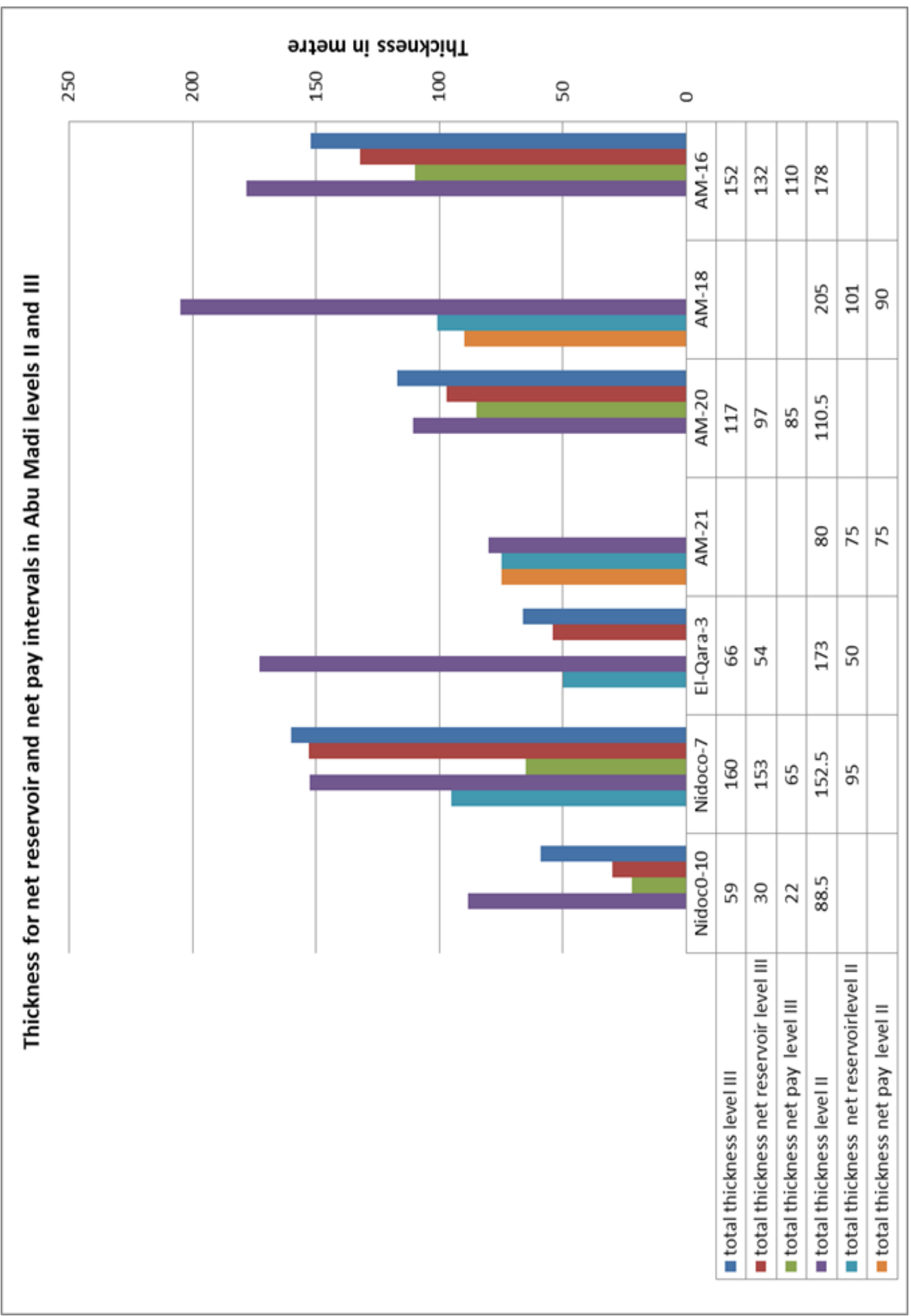

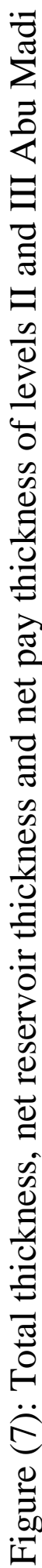



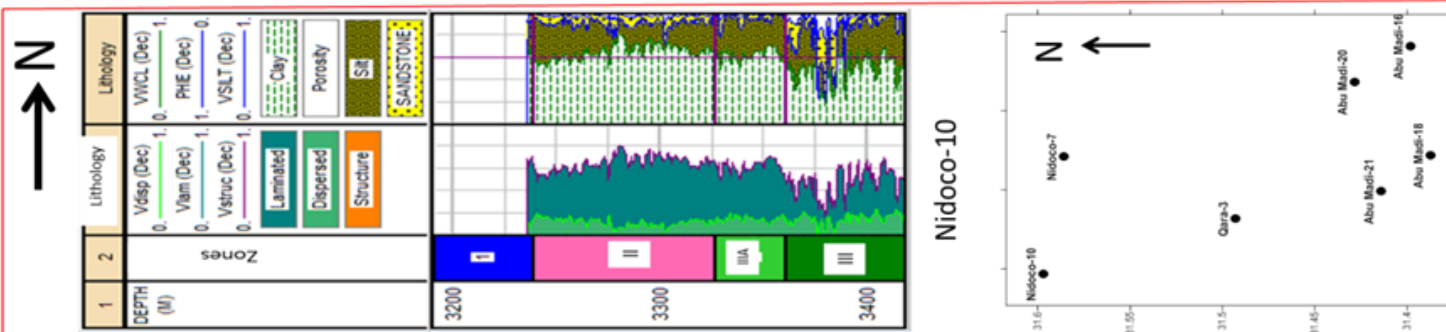

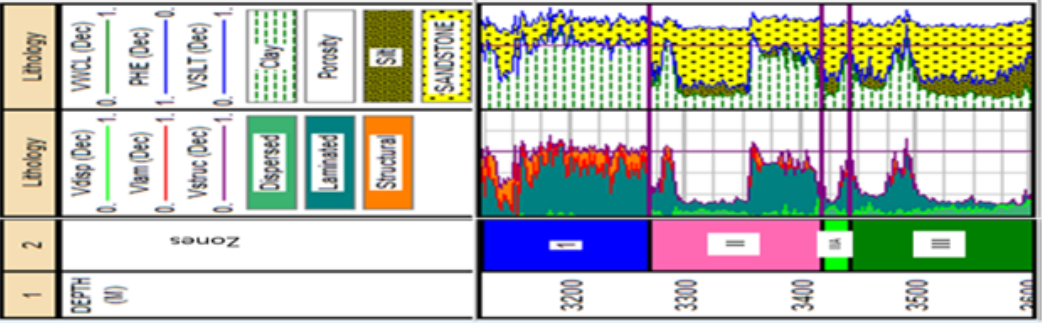

\section{旁}

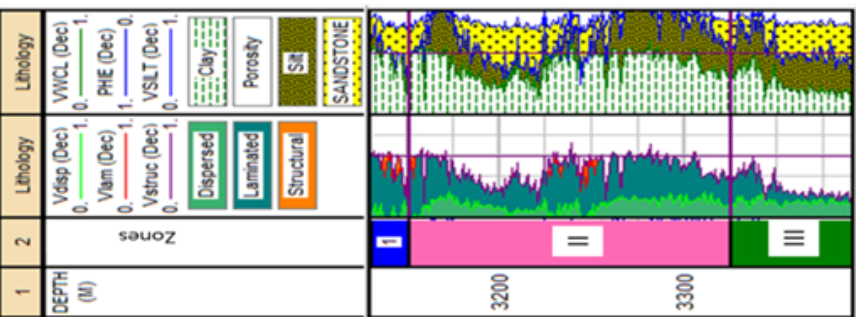
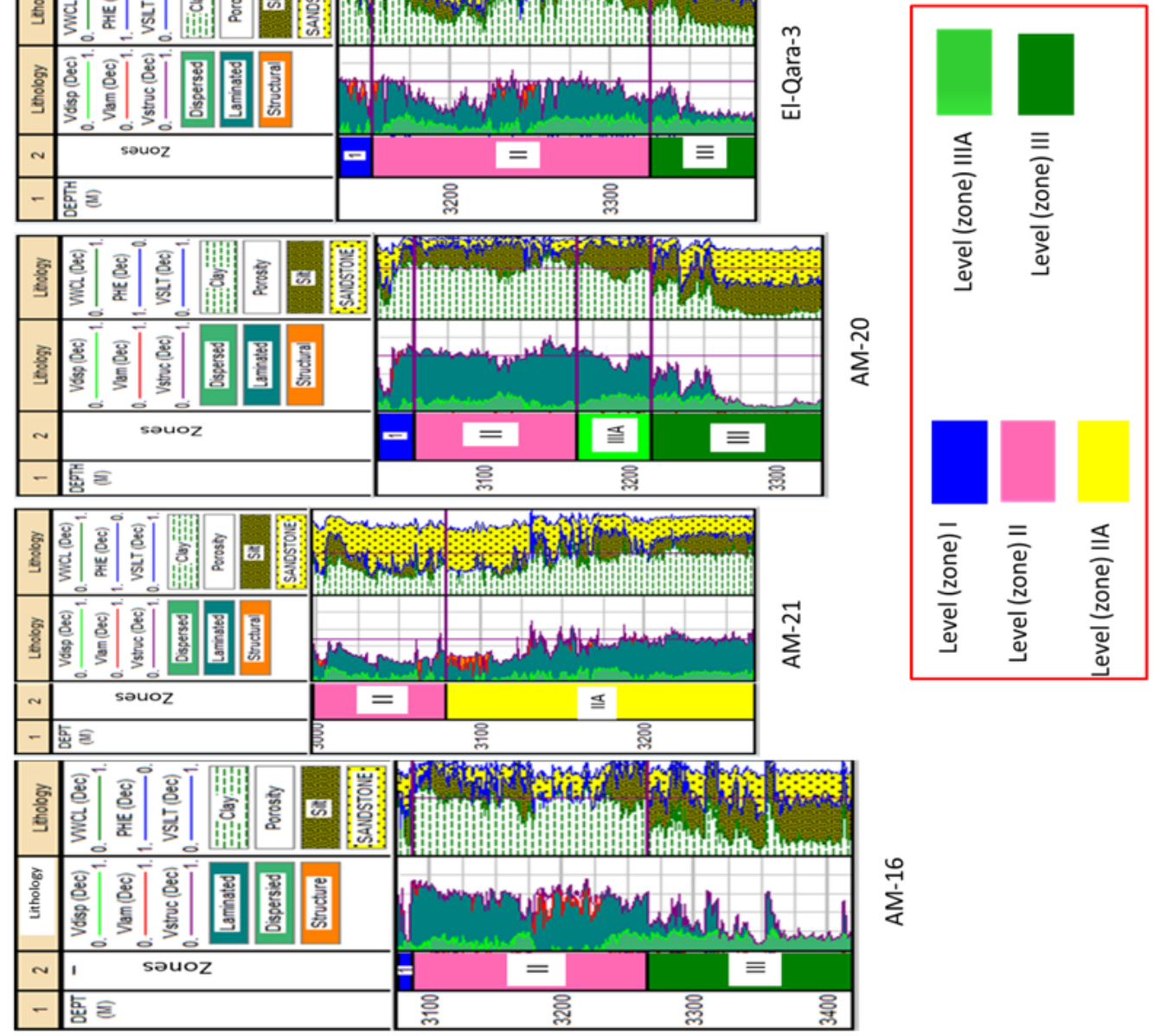

$\sum_{\frac{1}{4}}^{1}$
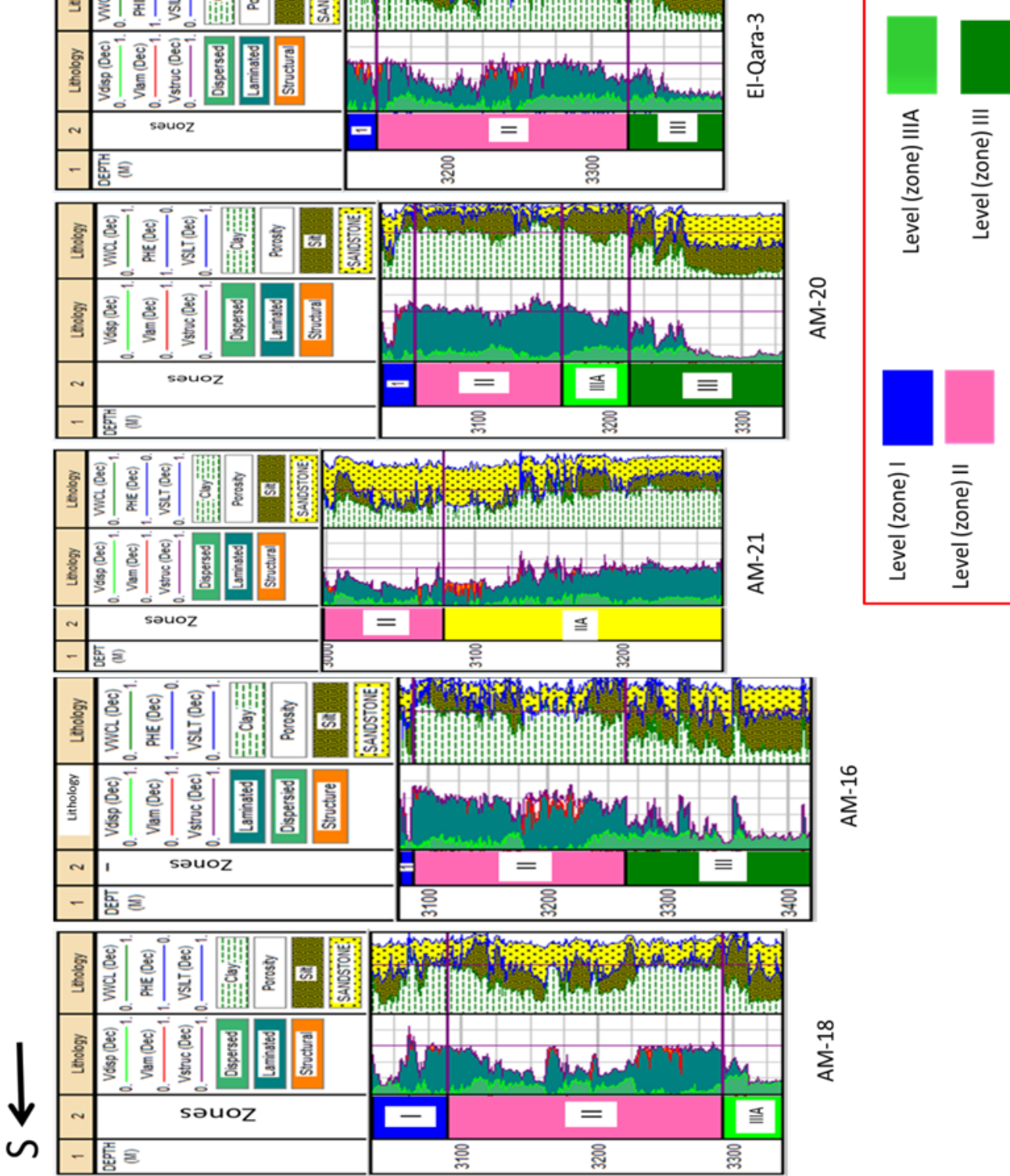

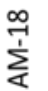



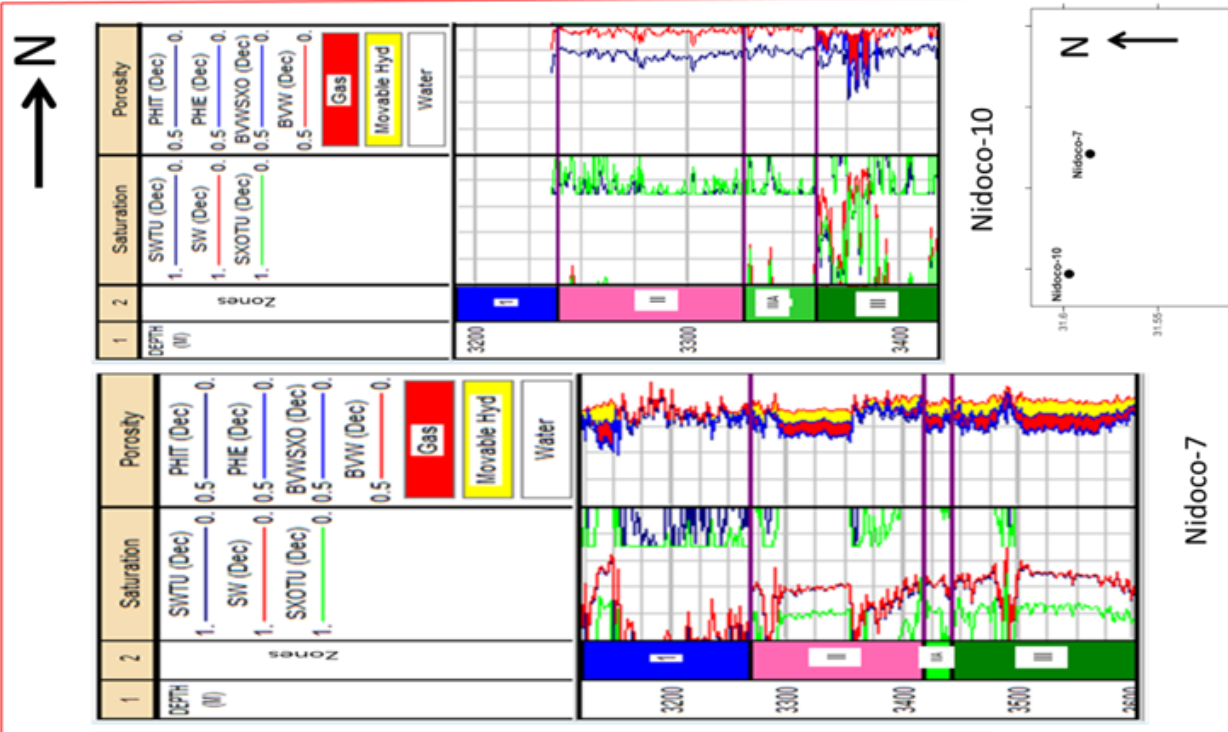

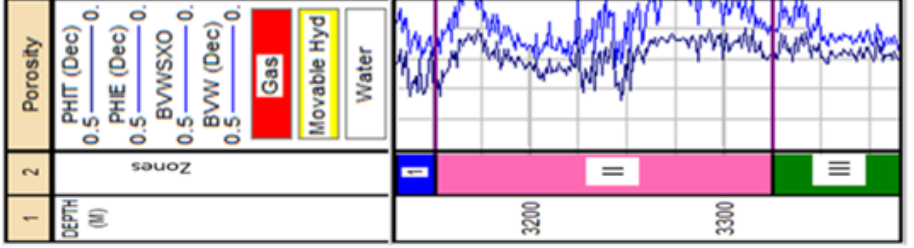
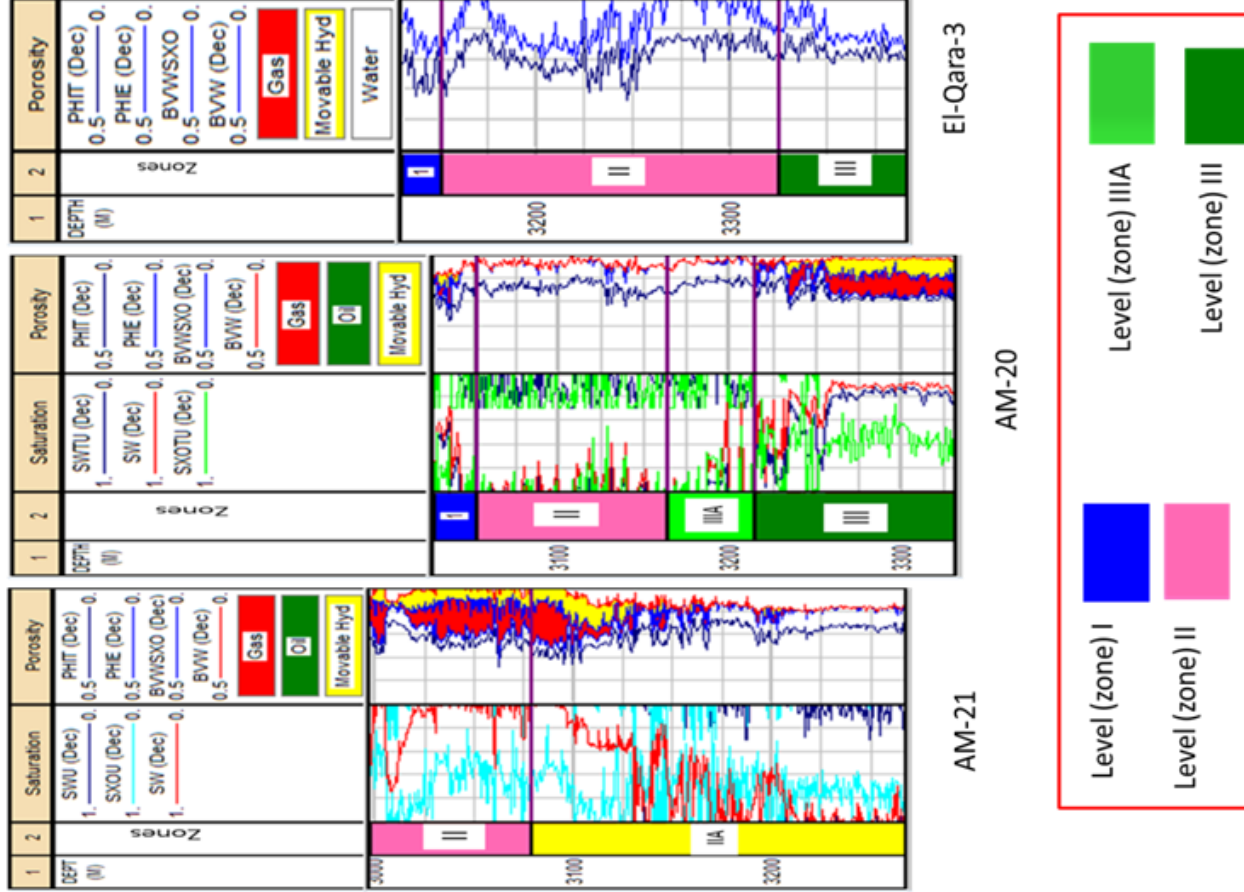

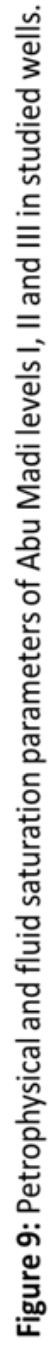

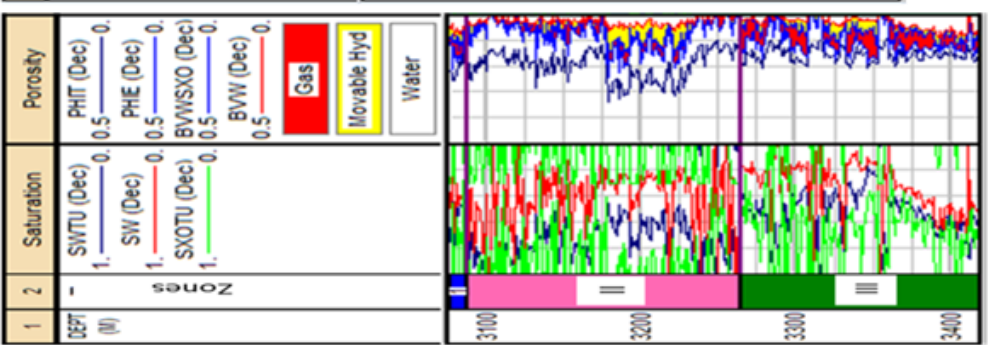

$$
\stackrel{0}{\frac{1}{4}}
$$
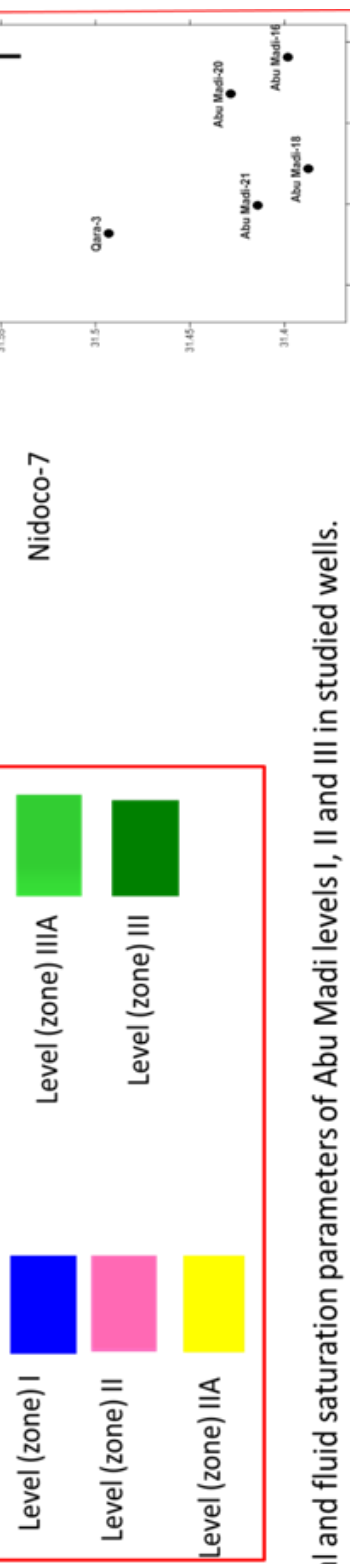

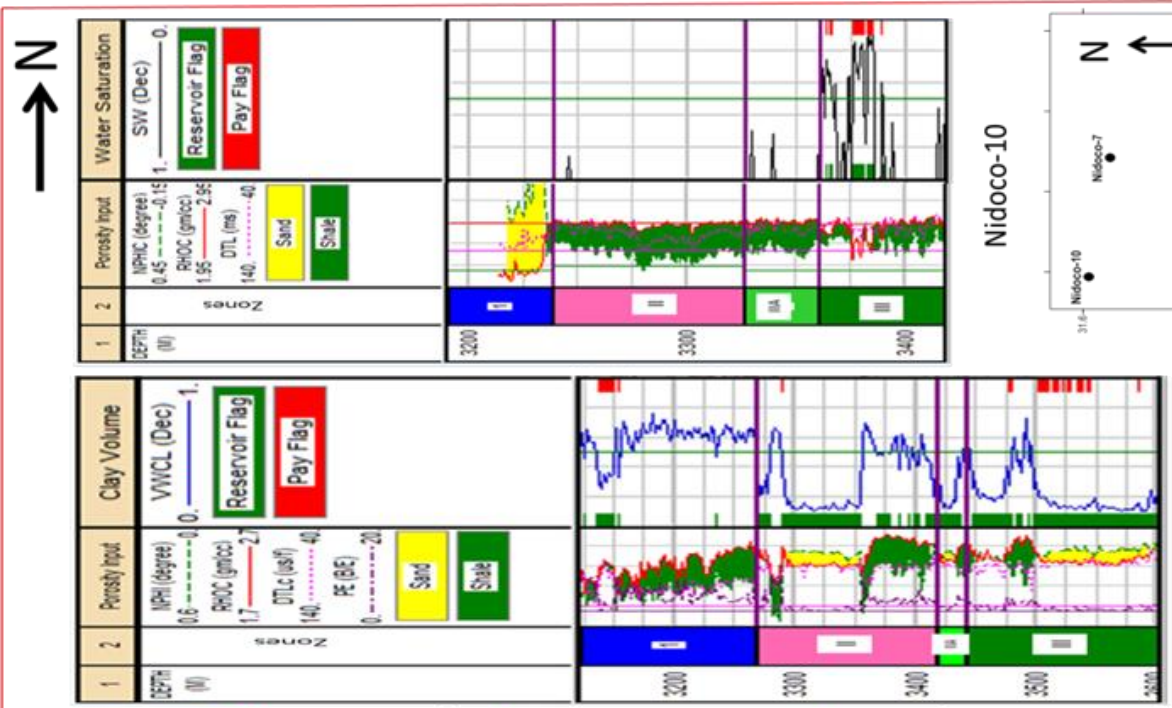

흥
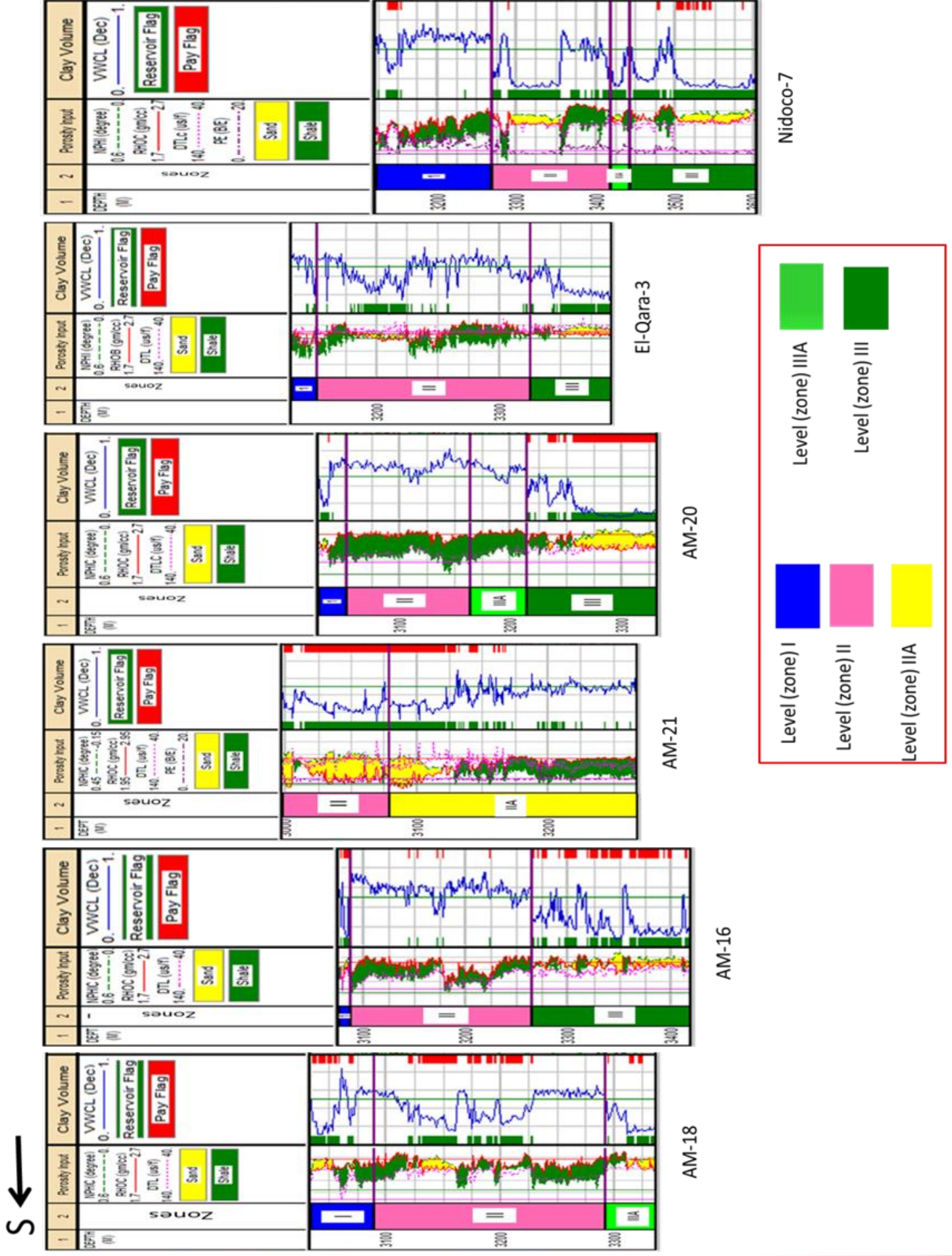


\section{Isoparametric maps of petrophysical parameters:}

The horizontal distribution maps represent the configuration of the petrophysical analysis in the study area. These maps include thickness maps (isopach) and the petrophysical parameters maps, which include; shale content $\left(V_{s h}\right)$, effective porosity (PHIE), water saturation $\left(S_{w}\right)$, and hydrocarbon saturation $\left(S_{h}\right)$ distribution maps of Abu Madi Formation, levels II and III.

\section{Shale volume distribution map $\left(V_{s h}\right)$}

The shale content $\left(\boldsymbol{V}_{\boldsymbol{s} \boldsymbol{h}}\right)$ of Abu Madi level II reservoir (Figure 11) decreases toward the southwestern and northeastern parts and increase at the middle, southeastern and northwestern parts. In Abu Madi level III reservoir (Figure 11). The shale volume is decreasing at the eastern direction and increasing slowly toward the west (the southwestern part is blanked, because the level III is missing in wells $\mathrm{AM}-18$ and $\mathrm{AM}-21)$.

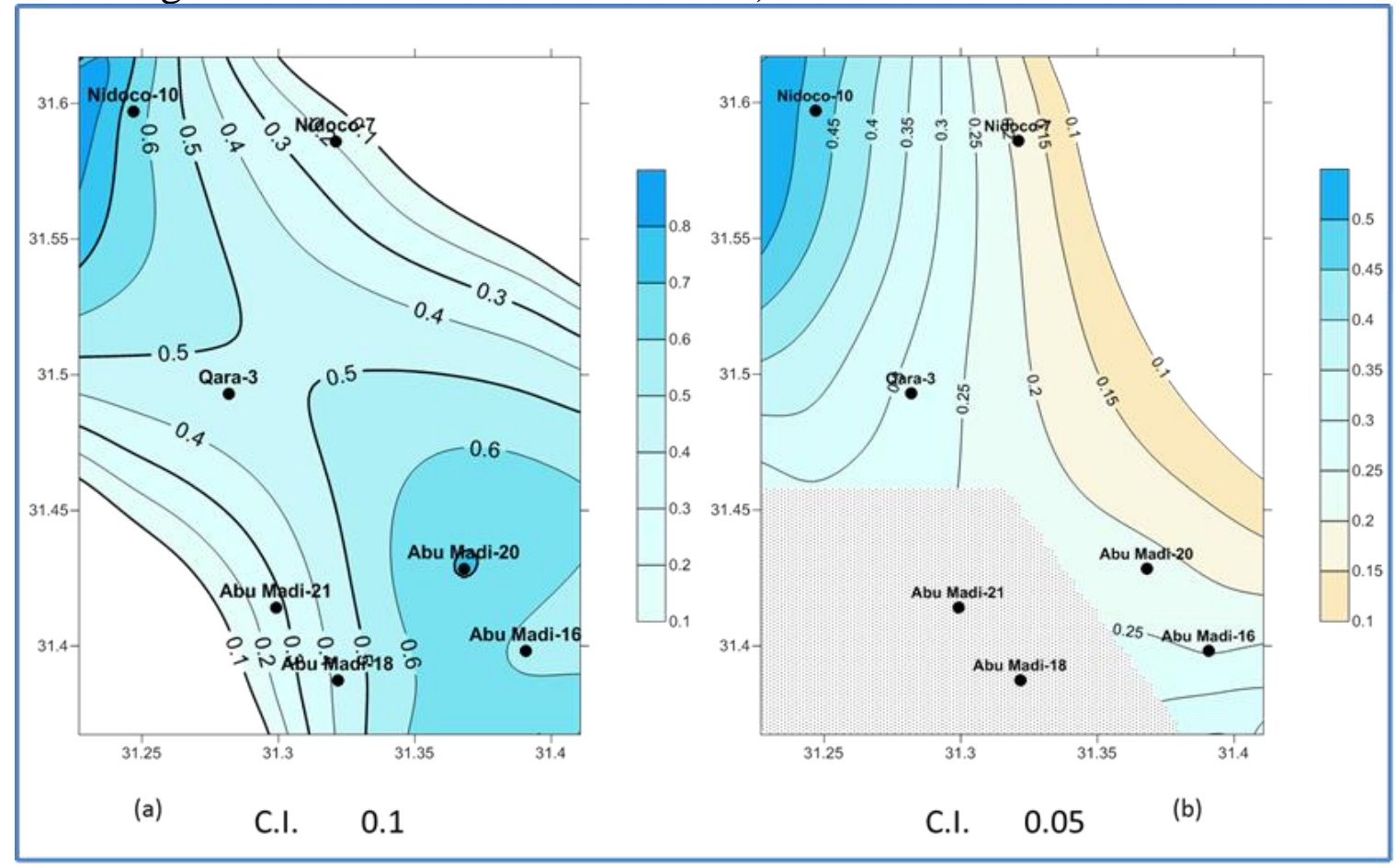

Figure (11): Shale volume distribution maps (a) for Abu Madi level II and (b) for Abu Madi level III.

\section{Effective porosity (PHIE) distribution map}

The effective porosity $\left(\emptyset_{\text {eff }}\right)$ of Abu Madi level II reservoir increase toward northeast and southwest directions and decreasing toward the middle part as shown in (Figure 12). While for Abu Madi level III reservoir, the effective porosity increases toward the east and northeastern parts, but decreases at the west, direction (the southwestern part is blanked, because level III is missing in wells $\mathrm{AM}-18$ and $\mathrm{AM}-21$ ) as shown in (Figure 12). 


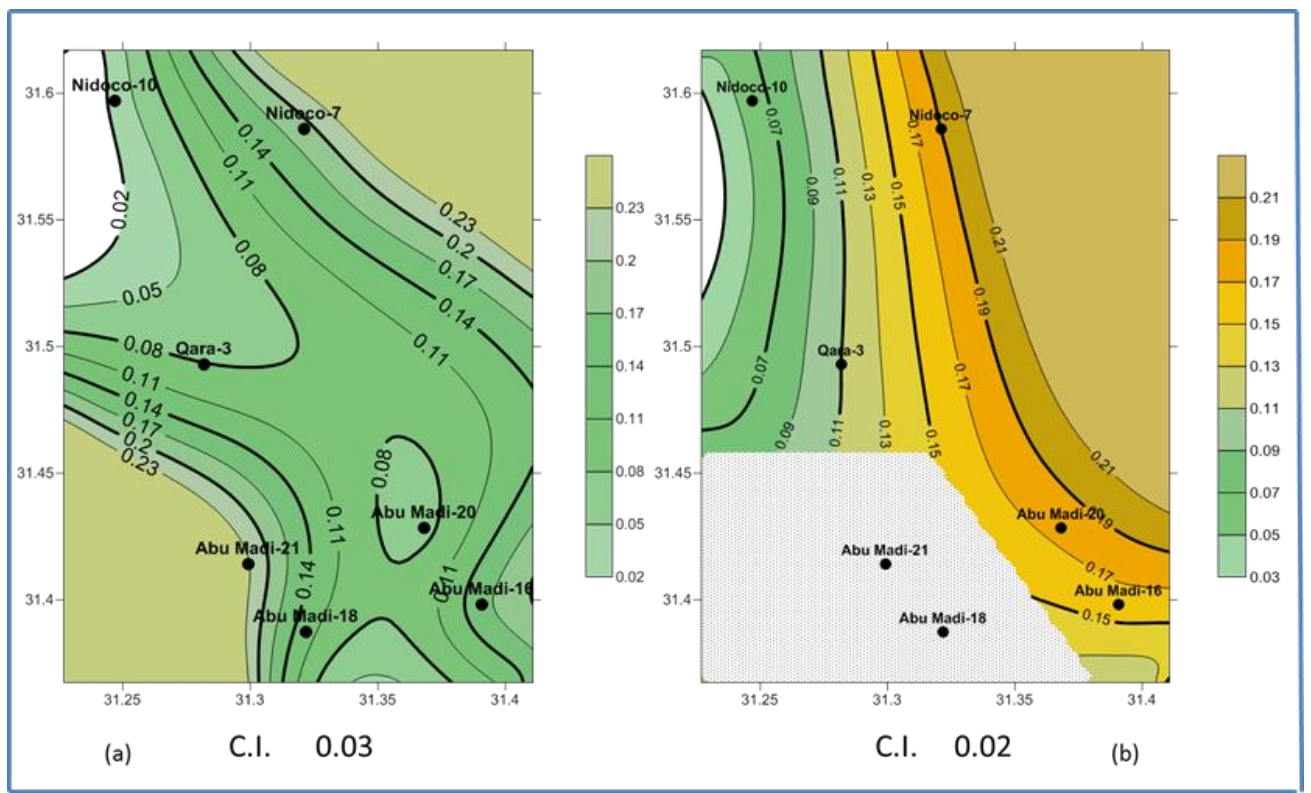

Figure (12): Effective porosity distribution maps (a) for Abu Madi level II and (b) for Abu Madi level III.

\section{Water saturation $\left(S_{w}\right)$ distribution map}

The water saturation $\left(\boldsymbol{S}_{\boldsymbol{w}}\right)$ of Abu Madi level II reservoir shows an increasing of the values at the northwestern and eastern parts, but decrease toward the northeastern and southwestern parts, as shown on (Figure 13). While for the Abu Madi level III reservoir the water saturation decreases at the middle, northwestern and southeastern parts and increasing toward the northeastern direction, as shown on (Figure 13) (the southwestern part is blanked, because the level III is missing in wells AM - 18 and AM - 21).

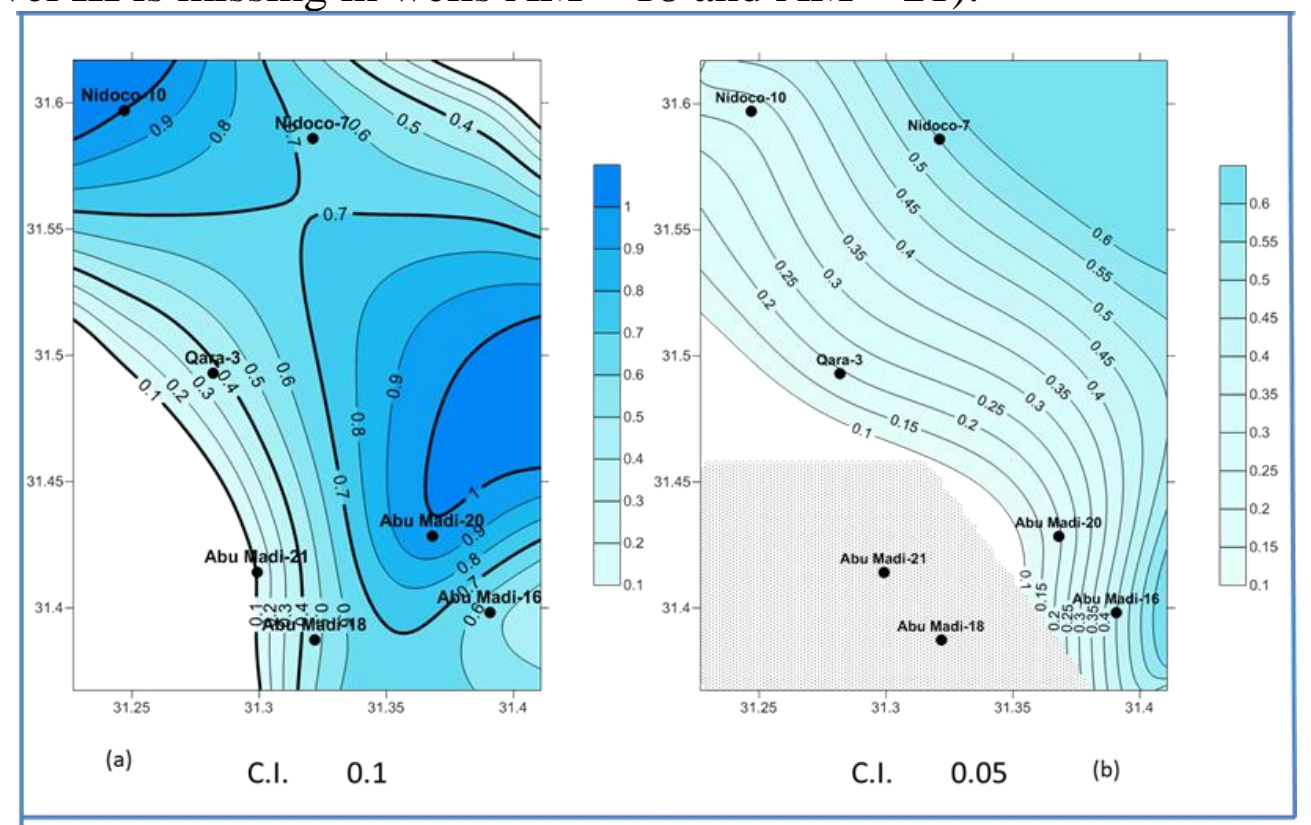

Figure (13): Water saturation distribution maps (a) for Abu Madi level II and (b) for Abu Madi level III. 


\section{Hydrocarbon saturation $\left(S_{h}\right)$ distribution map}

The hydrocarbon saturation $\left(\boldsymbol{S}_{\boldsymbol{h}}\right)$ of Abu Madi level II reservoir shows a decreasing in values at eastern and northwestern parts and increase toward northeastern and southwestern parts, as shown on (Figure 14). While for Abu Madi level III reservoir the hydrocarbon saturation increases at southeastern, middle and northwestern parts, but it decreases in the northeastern direction, as shown on (Figure 14) (the southwestern part is blanked, because the level III is missing in wells AM - 18 and AM - 21).

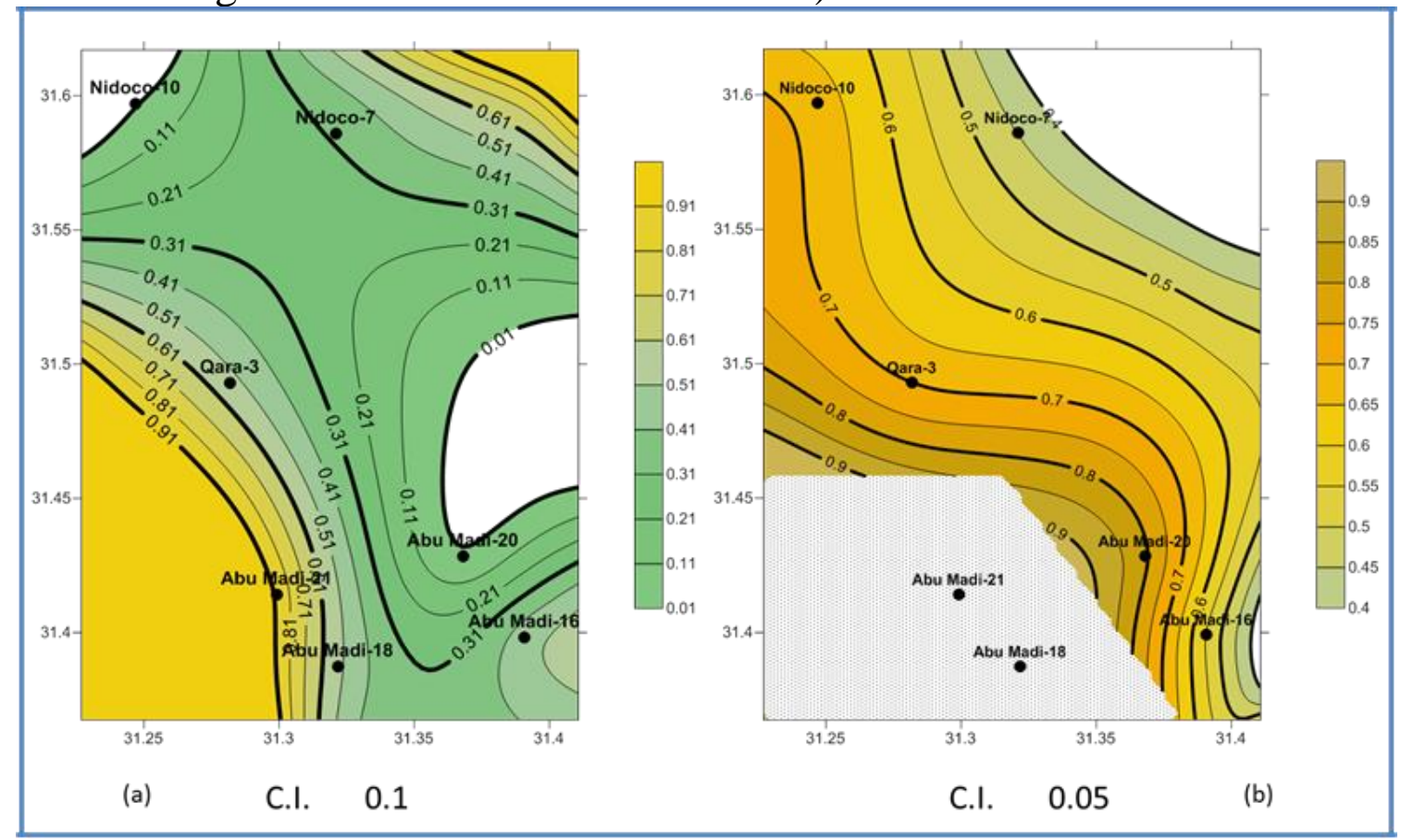

Figure (14): Hydrocarbon saturation maps (a) for Abu Madi level II and (b) for Abu Madi level III.

\section{Thickness distribution maps (isopach)}

The thickness distribution map for Abu Madi level II (Figure 15) shows that the thickness increases toward the southwestern and northeastern directions (reach $270 \mathrm{~m}$ in well AM-21 and reach $155 \mathrm{~m}$ in well Nidoco-7), then it is decreasing toward the middle, northwestern and southeastern directions (reach $90 \mathrm{~m}$ in well Nidoco-10 and reach $110 \mathrm{~m}$ in well AM-20, but it increasing again in that direction reaching to $175 \mathrm{~m}$. in well AM-16).

The thickness of Abu Madi level III decreasing toward the southwestern direction (where it is missing in wells AM-18 and AM-21), then the thickness increasing gradually toward the middle, southeastern, northwestern and northeastern directions (Figure 15).

The thickness distribution map of level II net reservoir (reservoir flag) (Figure 16), shows that the net reservoir increases at northeastern and southwestern directions (reaching $140 \mathrm{~m}$ in well AM-21 and reach to $100 \mathrm{~m}$ in well Ndoco- 
7), at the middle part the thickness reach to $35 \mathrm{~m}$ in well El-Qara-3. In the northwestern and southeastern direction the thickness of the net reservoirs reach to zero $\mathrm{m}$. (where the lithology of level II in wells Nidoco-10, AM-16 and AM-20 is sandy-shale).

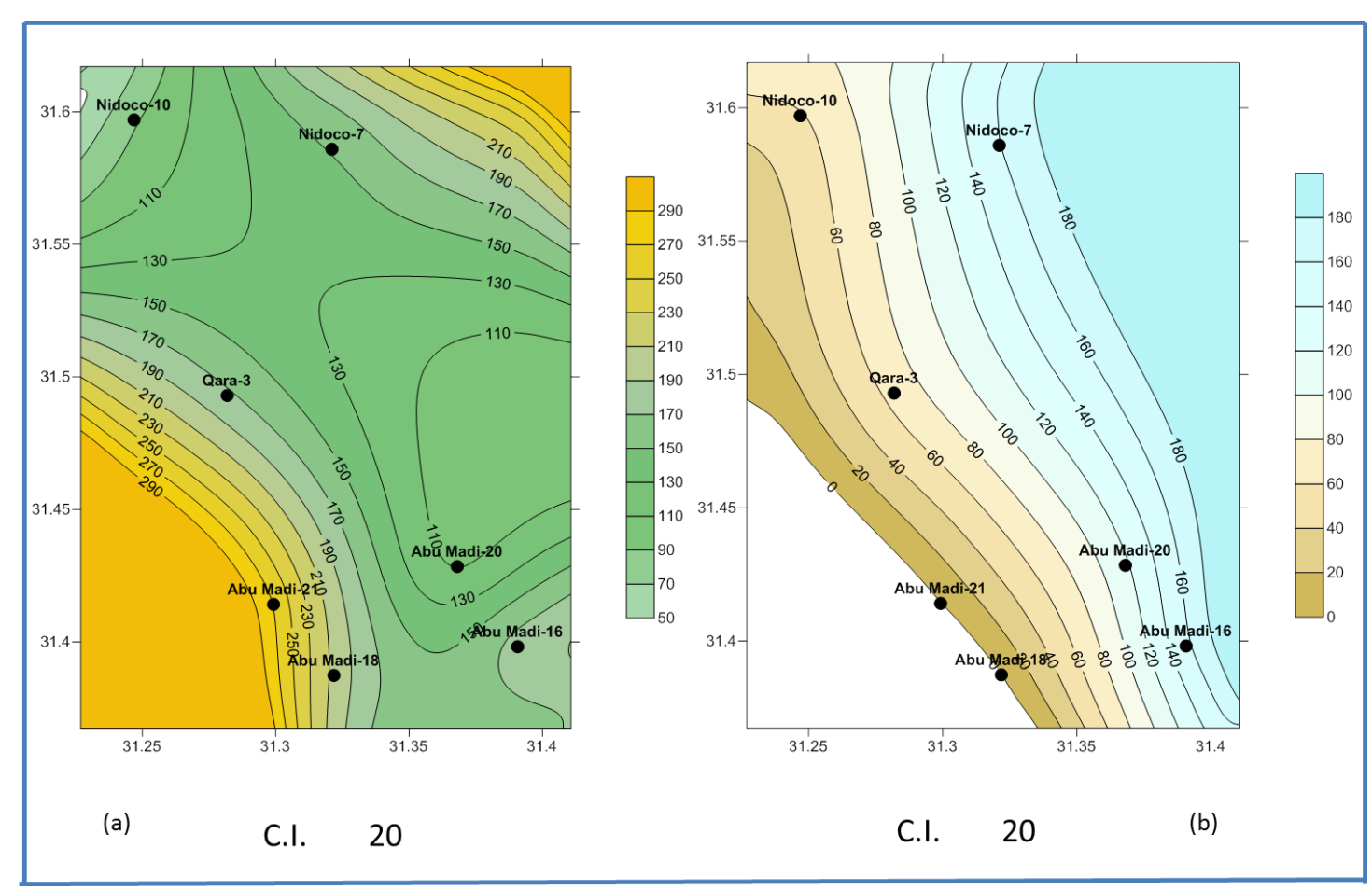

Figure (15): Total thickness distribution map, (a) Level II and (b) Level III reservoirs, Abu Madi Formation.

The thickness distribution map of level III net reservoir (reservoir flag) (Figure 16), shows that the net reservoir thickness of level III decreasing toward the southwestern direction (where it is missing in wells AM-18 and AM-21), then the thickness increasing gradually toward the middle, southeastern, western, northwestern and northeastern directions (Figure 16).

The thickness distribution map of Abu Madi level II Net pay (pay flag) (Figure 17), shows that the net pay thickness of level II reaching to zero in the middle, northwestern and southeastern parts (where the lithology of level II is sandy shale in the available drilled wells on that parts). Then it increases in the northeastern and southwestern directions.

The thickness distribution map of Abu Madi level III Net pay (pay flag) (Figure 17), shows that the net pay thickness of level III reaching to zero in the southweastern direction (where level III is missing in wells AM-18 and AM-21). Then the thickness increases gradually toward the middle, southeastern, northwestern and northeastern directions. 


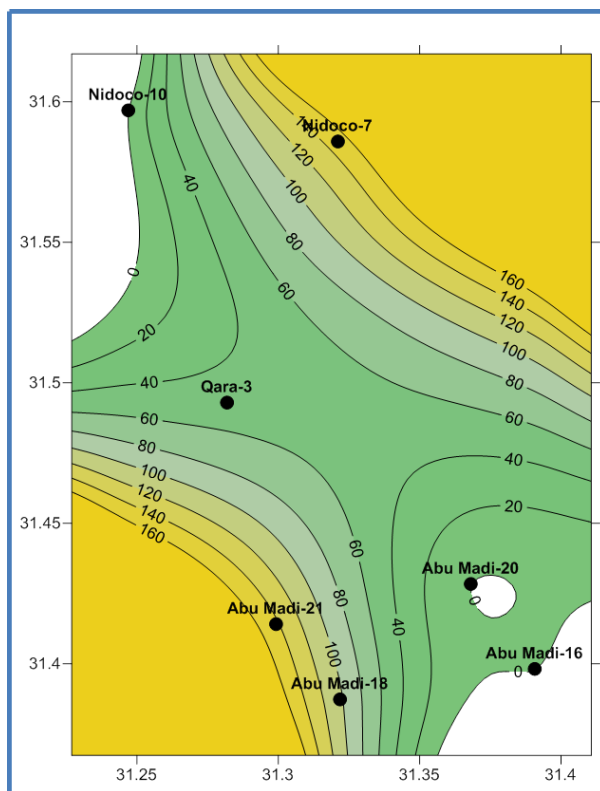

(a)

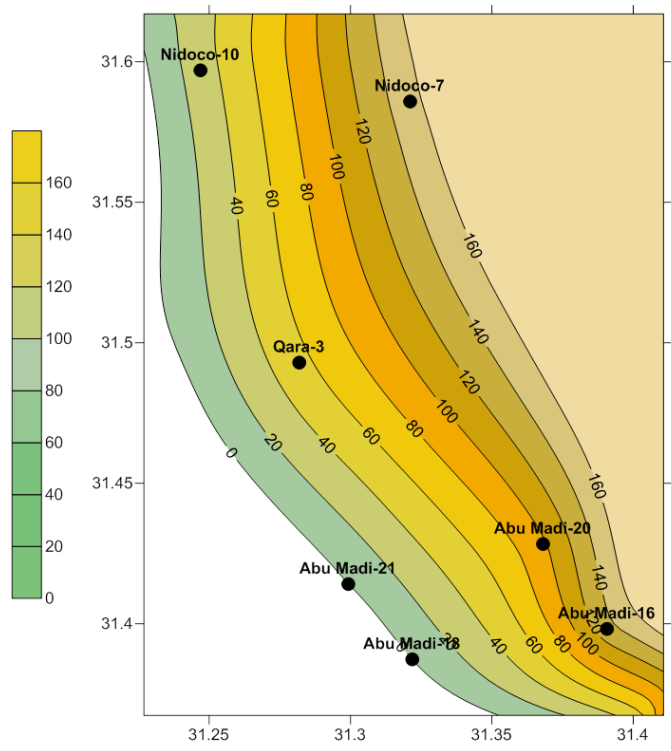

C.I. 20

(b)

Figure (16): Net reservoir (reservoir flag) thickness distribution map, (a) Level II and (b) Level III reservoirs, Abu Madi Formation.

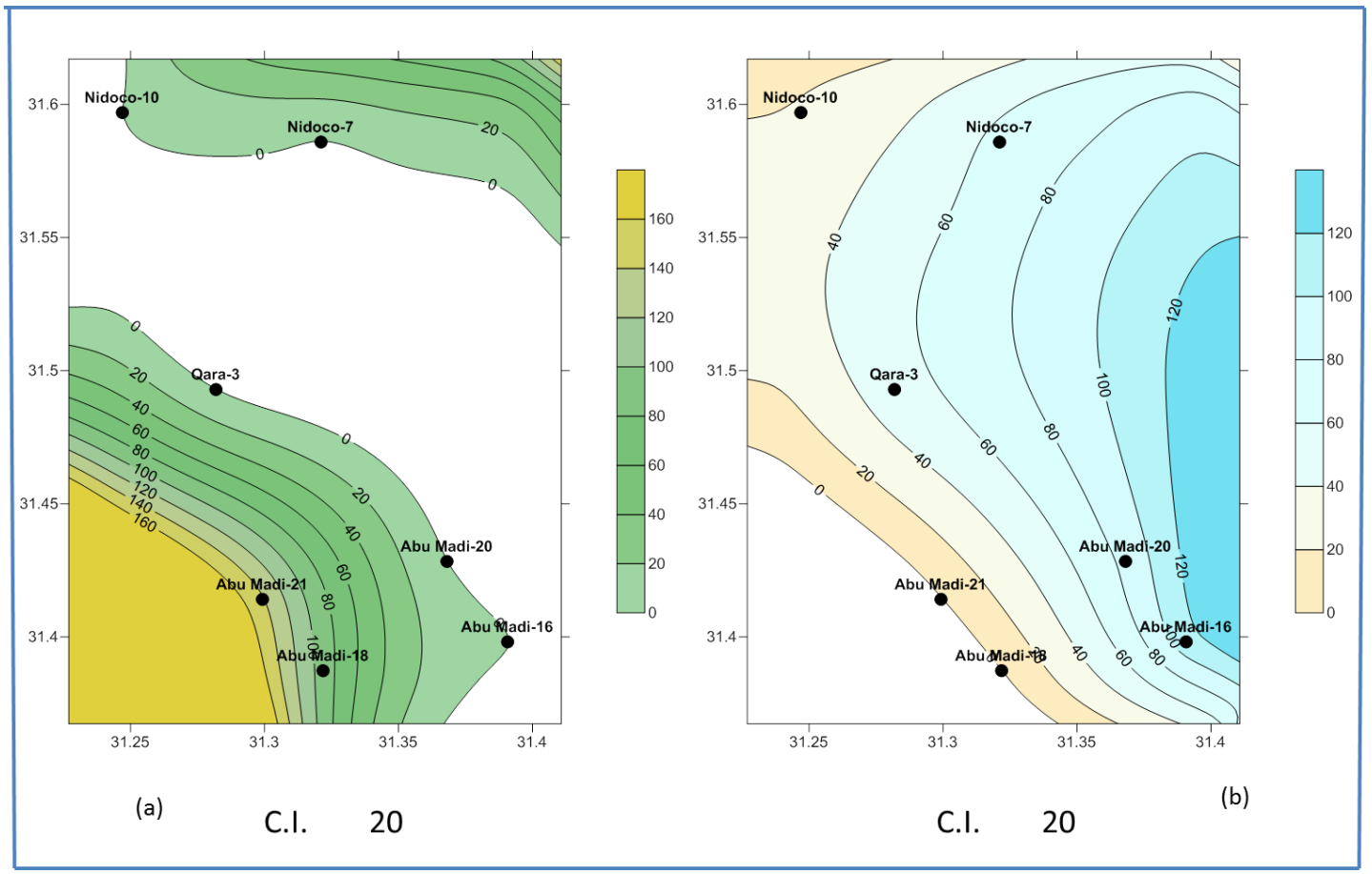

Figure (17): Net pay (pay flag) thickness distribution map, (a) Level II and (b) Level III reservoirs, Abu Madi Formation. 


\section{Conclusion}

The aim of this study is to make full subsurface and petrophysical evaluation of Abu Madi Levels II and III reservoirs, Abu Madi-El-Qara-Nidoco area, Nile Delta of Egypt. In addition to the petrophyical characteristics of the rock units Abu Madi Levels II and III, this study performs the hydrocarbon potentialities of the study area.

Different cross-plots are constructed to display the reservoir mineralogy as the neutron-density, neutron-sonic and $\mathrm{M}-\mathrm{N}$ crossplots. These cross-plots reflect that; the main lithological type in level III is sandstone intercalated with shale in all available wells, while the lithological type in Level II is shaly sandstone in wells AM-18, AM-21, El-Qara-3 and Nidoco-7, but it is sandy-shale in wells AM-16, AM-20 and Nidoco-10.

The main lithology of the reservoir is sandstone which is intercalated mainly with dispersed clay type and minor laminated shale in Level III and dispersed to laminated shale in Level II.

The Cut-offs and summation module allows us to interactively define 'Net Reservoir' and 'Net Pay' cut-off criteria and zones, and to calculate the average petrophysical properties of porosity, clay volume and water saturation for each zone within a petrophysical interpretation.

The effective thickness of Abu Madi Level II, net reservoir and net pay, increase toward northeastern and southwestern direction of the study area, while the effective thickness of Abu Madi Level III, net reservoir and net pay, increase in the northeastern and eastern parts.

The effective porosity of Abu Madi Level II increases toward the northeastern and southwestern direction of the study area, while the effective porosity of Abu Madi Level III increases toward the east and northeastern directions.

The shale content of Abu Madi Level II increases in the middle, northwestern and southeastern parts of the study area. While the shale content of Abu Madi Level III increases in the northwestern part.

The hydrocarbon saturation of Abu Madi Level II increases in the northeastern and southwestern parts of the study area, while the hydrocarbon saturation of Abu Madi Level III increases in the middle, northwestern and southeastern parts of the study area.

The lateral distribution of the petrophysical parameters indicate that the most favorable places for hydrocarbon reservoirs occupy the northeastern and southwestern parts for Abu Madi level II reservoir and in the middle, the middle-west, the middle-east and the southeastern parts for Abu Madi Level III reservoir. It is recommended to drilling more wells in these parts. 


\section{Acknowledgement}

We would like to thank the Egyptian General Petroleum Corporation (EGPC), also, thanks due to the authority of PETROBEL Company (Cairo, Egypt) for providing the required well log data for Abu Madi-El-Qara-Nidoco area

\section{References}

Asquith, G. B. and Gibson, C. R. (1982): Basic Well Log Analysis for Geologists, Published by the American Association of Petroleum Geologist, Tulsa, Oklohoma, U.S.A.

Azzam, A. S. (1994): An integrated seismo-facies and seismo-tectonic study of the Nile Delta of Egypt, utilizing common-depth seismic reflection data. Ph.D. Thesis, Geology Department, Faculty of Science, Ein Shams University, Cairo, Egypt, 240 P.

Barakat, M. and Dominik, W. (2010): Seismic studies on the Messinian rocks in the onshore Nile Delta, Egypt. EAGE, June 2010, p.p. 14 - 17.

Clavier, C., Coates, G. and Dumanoir, J. (1977): the theoretical and experimental bases for the dual water model for interpretation of shaly sands. SPE paper No. 6859, 35P.

Egyptian General Petroleum Corporation (1994): Nile Delta and north Sinai fields, discoveries and hydrocarbon potentialities (as comprehensive overview). EGPC-Cairo, Egypt, 387 P.

El-Gezeery, M. N., Mohsen, S. M. and Farid, M. I. (1972): Sedimentary basins in Egypt and their Petroleum prospects. $8^{\text {th }}$ Arab Pet. Cong., Algiers, Vol. 2, No. 83, pp. 1-13.

El-Heiny, I. and Morsi, S. (1992): Stratigraphic correlation of Neogene sediments in the eastern Nile Delta and Gulf of Suez, Egypt. $11^{\text {th }}$ Exploration International Conference, EGPC, Cairo, pp. 166-193.

El-Heiny, I. and Enani, H. (1996): Regional stratigraphic interpretation pattern of Neogene sediments, Northern Nile Delta. Egypt. $13^{\text {th }}$ Exploration and Production Conference, EGPC, Cairo, Egypt, pp. 1438.

Kamel, H., Eita, T. and Sarhan, M. (1998): Nile Delta hydrocarbon potentialities. $14^{\text {th }}$ Exploration and Production Conf., EGPC, Cairo, pp. 485-503.

Kostandi, A. B. (1959): Facies maps for the study of the Palaeozoic and Mesozoic sedimentary basins in the Egypt region. $1^{\text {st }}$ Arab Pet. Cong., Egypt, 12 P.

Rider, M. H. (1986): Geological interpretation of well logs. Blakie, Glasgow, and London - John Wiley, and Sons, New York. 
Rizzini, A., Vezzani, F., Cococcetta, V. and Milad, G. (1978): Stratigraphy and sedimentation of Neogene- Qaternary section in the Nile Delta area. Marine Geology Vol. 27, pp. 327-348.

Said, R. (1973): Evaluation of Eocene-Miocene sedimentation patterns in parts of northern Egypt. AAPG Bull., Vol. 60, pp. 34-64.

Said, R. (1990): The Geology of Egypt - 734 p. A. Balkema Publishers, USA.

Salem, M. (1976): Evolution of the Eocene-Miocene sedimentation pattern in northern Egypt. AAPG-Bull. Vol. 60: pp. 34-64.

Schlumberger (1972): Log Interpretation, Volume I, Principles. Park Avenue, New York.

Schlumberger (1974): Log Interpretation, Volume II, Applications. Schlumberger Limited.

Schlumberger (1984): Geology of Egypt pp.1-64. - Paper presented at the Well Evaluation Conference, Schlumberger, Cairo.

Shata, A. and El-Fayoumy, I. (1970): Remarks on the regional geological structure of the Nile Delta. In: Hydrology of Deltas. IANSHIUNESCO Bucharest Symposium.Vol.i. UNESECO. Paris, pp. 189-197.

Zaghloul, Z. M., Taha, A. A. and Gheith, A. M. (1977a): Microfacies studies and paleoenvironmental trends on the subsurface sediments of Kafr El Sheikh well No. 1, Nile Delta area. Bull. Mansoura Uni. Vol. 5, pp. 113-138.

Zaghloul, Z. M., Taha, A. A., Hegab, O. and El Fawal, F. (1977b): The Neogene-Quaternary sedimentary basins of the Nile Delta Egypt. - J. Geol. Vol 21, pp 1-19.

Zaghloul, M. Z., Shaaban, F. F. and Yousef, A. F. (1999): Mesozoic and Cenozoic sedimentary basins, Nile Delta, Egypt. Proc. of the $1^{\text {st }}$ International Symp. Mansoura. Univ. Egypt, pp. 13-20. 


\section{ملخص}

تهدف الدراسة الى تقييم خصائص خزان الميوسين المتأخر لمتكون أبو ماضي (المستوى الثاني و الثالث لمنكون ابو ماضى) في منطقة أبو ماضي - القرعة ـ نيدوكو، شمال دلتا النيل، مصر. تقع منطقة الدر اسة بين خطى الطول 48" 13' 31 - 36" 24' 21 " شرقا و خطى عرض 36" 21 21 12" 37' o31 شمالا. تم استخدام بيانات سجلات الابار لسبعة آبار في هذه الدراسة. تم فحص الخصائص البتروفيزيائية للتشكيلات المدروسة بدقة لتوضيح إمكانات تواجد الهيدروكربونات. تم عرض الاختلاف الر أسي للخصائص البتروفيزيائية بواسطة عرض الليسوساتيور اشن كروسبلوت. تم إنشاء خر ائط توزيع الخصائص (المحتوى الطفلى، المسامية، تشبع السوائل، سماكة الخزان و التشبع الهيدروكربوني) لتمثيل التباين الجانبي للخصائص البتروفيزيائية. يظهر نموذج الصخر الطفلى أن الصخر الطفلى السائد هو أساسا من أنواع مشتتة وصفائحية. تبين الكروسبلوت المختلفة ان الحجر الصخري الرئيسي هو الحجر الرملي مقحم أساسا مع صخور طفلية مشتنة وصفائحية طفيفة في المستوى الثالث لمتكون ابو ماضى ومششتنة وصفائحية في المستوى الثاني لمتكون ابو ماضى. تبين الدراسة أيضا أن متكون أبو ماضي له مسامية من ضعيفة الى جيدة جدا تتراوح من 0,03 إلى 0,22 للمستوى الثاني ومن 0,06 إلى 0,19 للمستوى الثالث. توضح هذة الدراسة ان الأماكن الاكثر ملاءمة كخز انات هيدروكربونية بالنسبة للمستوى الثانى لمتكون ابو ماضى تقع فى الجزء الجنوبى الغربى من منطقة الار اسة, بينما الأماكن الاكثر ملائمة كخزانات هيدروكربونية بالنسبة للمستوى الثالث لمتكون ابو ماضى فهى تقع فى الاجز اء الاوسط والاوسط الغربى والاوسط الثرقى و الجنوبى الثرقى امنطقة الدر اسة. 